\title{
Chile: Financial System Stability Assessment, including Reports on the Observance of Standards and Codes on the following topics: Monetary and Financial Policy Transparency, Banking Supervision, and Securities Regulation
}

This Financial System Stability Assessment on Chile was prepared by a staff team of the International Monetary Fund and the World Bank as background documentation for the periodic consultation with the member country. It is based on the information available at the time it was completed on

July 14, 2004. The views expressed in this document are those of the staff team and do not necessarily reflect the views of the government of Chile or the Executive Board of the IMF.

The policy of publication of staff reports and other documents by the IMF allows for the deletion of market-sensitive information.

To assist the IMF in evaluating the publication policy, reader comments are invited and may be sent by e-mail to publicationpolicy@imf.org.

Copies of this report are available to the public from

International Monetary Fund $\bullet$ Publication Services

700 19th Street, N.W. • Washington, D.C. 20431

Telephone: (202) $6237430 \bullet$ Telefax: (202) 6237201

E-mail: publications@imf.org • Internet: http://www.imf.org

Price: $\$ 15.00$ a copy

\section{International Monetary Fund} Washington, D.C. 



\title{
INTERNATIONAL MONETARY FUND
}

\section{CHILE}

\section{Financial System Stability Assessment}

\author{
Prepared by the Monetary and Financial Systems and Western Hemisphere Departments
}

\author{
Approved by Ulrich Baumgartner and Anoop Singh
}

July 14, 2004

The Financial System Stability Assessment is based on the work of the joint IMF-World Bank missions to Chile in December 2003 and March 2004. The missions were co-led by Alain Ize (IMF) and Augusto de la Torre (World Bank) and included Marie-Thérèse Camilleri, Marco Espinosa, Eva Gutierrez, Meral Karasulu, and Silvia Ramírez (all IMF); Ernesto Aguirre, Sissi Frank, Thomas Glaessner, Roberto Rocha, Sophie Sirtaine, Constantinos Stephanou, and Craig Thorburn (all World Bank); Juan Ortiz (Bank of Spain), Brian Quinn (formerly Bank of England), Irit Mendelson (Bank of Israel), Marc Bayle (European Central Bank), and Jonathan Katz (U.S. SEC).

The Chilean banking system was found to be sound, resilient to shocks, and well-supervised. Banks are well capitalized, profitable, internationally integrated, and have relatively low nonperforming loans. Stress tests indicate they would absorb sizable macroeconomic shocks with only a moderate impact on their solvency. Although bank competition remains limited, it has increased significantly in recent years.

Private pension funds (AFPs) are by far the dominant institutional investors in the country. There is room to enhance their impact on the domestic financial system by a judicious relaxation of their overly restrictive investment regime without undermining their fiduciary function. In addition, current efforts to enhance competition in the industry should be intensified. The insurance sector faces some under-provisioning of risks, increased competition, and weaknesses in its resolution framework. The needed increase in provisions and reforms to the supervisory framework should be carefully planned and phased in.

Some important gaps in market infrastructure that limit market liquidity and investment need to be filled. This will require embedding more firmly in the law key concepts underlying securities clearance and settlement, organizing a market for securities lending, introducing multilateral netting arrangements, and formalizing the system of market makers. Valuation methods and contract standardization in securities markets and disclosure in the OTC market need to be improved. International financial reporting standards for listed firms should be introduced and a review of financial sector taxation conducted.

The current segmented financial oversight has functioned adequately so far but should adapt to the needs of an increasingly integrated and complex financial system. Reforms should focus, in the short term, on enhancing cooperation among regulators and filling the gaps in systemic market surveillance. For the medium term, legal changes will be needed to support the fully consolidated supervision of financial conglomerates. This move should be accompanied by further progress from rule-based to risk-based supervision, coupled with a strengthening of the financial and legal autonomy of the supervisory agencies and enhanced accountability.

The AML/CFT framework needs strengthening by: (i) addressing the limited sanctioning powers of the FIU and its inadequate access to information; and (ii) extending the range of application of AML/CFT to foreign exchange operators, securities firms and insurance companies.

FSSAs are designed to assess the stability and performance of the financial system as a whole and not that of individual institutions. FSSAs do not cover risks that are specific to individual institutions such as asset quality, operational or legal risks, or fraud. 


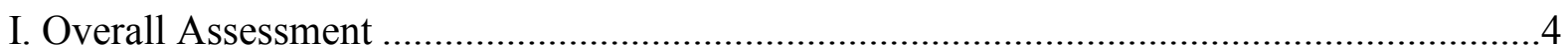

II. Financial Structure and Macroeconomic Environment ..................................................8

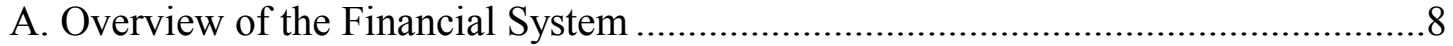

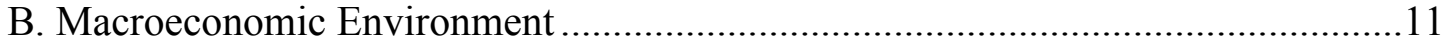

III. Macro-Financial Stability Analysis .................................................................... 13

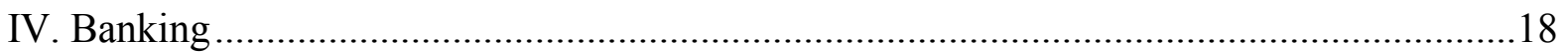

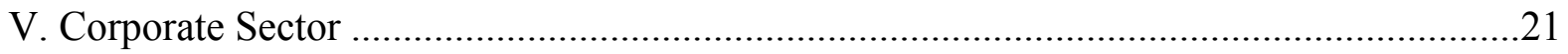

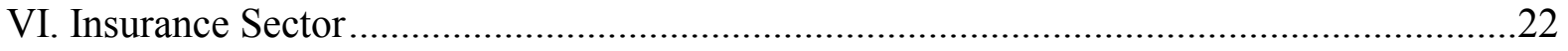

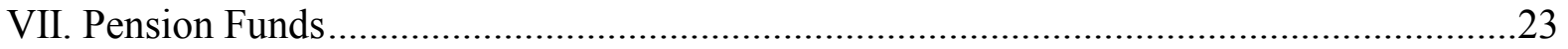

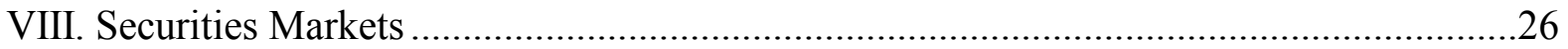

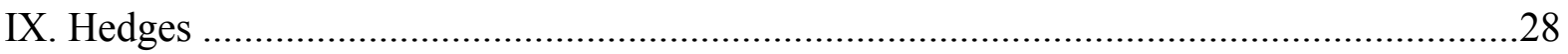

X. Cross-Sectoral Issues in Financial Oversight .........................................................29

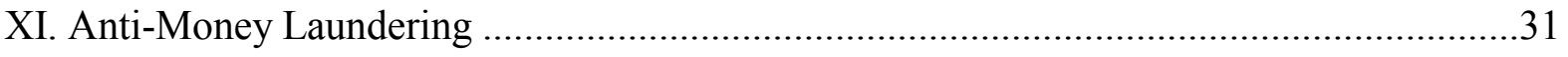

Box

1. Summary of Chile FSAP Recommendation ..........................................................

Appendix Tables

1. Chile: Selected Macroeconomic Indicators, 1997-2003 ..................................................47

2. Chile: Financial System Structure, 1997-2003 …...........................................................48

3. Chile: Financial Soundness Indicators , 1997-2003 …................................................49

Annex

I. Observance of Financial Sector Standards and Codes: Summary Assessments..................32

Basel Core Principles for Effective Banking Supervision ..........................................33

Implementation of the IOSCO Objectives and Principles of Securities .........................38

The IMF Code of Good Practices on Transparency in Monetary Policy .........................43 


\section{Glossary of Terms}

\begin{tabular}{|l|l|}
\hline AFPs & $\begin{array}{l}\text { Mandatory pension funds (Administradoras de } \\
\text { Fondos de Pensiones) } \\
\text { Anti-Money Laundering / Combating the Financing } \\
\text { of Terrorism }\end{array}$ \\
\hline CML/CFT & Bastral Bank of Chile (Banco Central de Chile) \\
\hline BCCh & Santiago Stock Exchange \\
\hline BCP & $\begin{array}{l}\text { Capital Adequacy Ratio (Regulatory Capital to Risk- } \\
\text { weighted Assets) }\end{array}$ \\
\hline Bolsa de Comercio de Santiago \\
\hline CAR & Draft Capital Markets II Reform Law \\
\hline CMII & Core Principle \\
\hline CP & $\begin{array}{l}\text { Centralized Securities Depository (Depósito Central } \\
\text { de Valores) }\end{array}$ \\
\hline DCV & Financial Conglomerates \\
\hline FCs & Uniformly Codified Statistical Form \\
\hline FECUs & Financial Intelligence Unit \\
\hline FIU & $\begin{array}{l}\text { Grupo de Acción Financiera Internacional Sud } \\
\text { Americano }\end{array}$ \\
\hline GAFISUD & International Accounting Standards \\
\hline IAS & International Financial Reporting Standards \\
\hline IFRS & Information Technology \\
\hline IT & Ministry of Finance \\
\hline MoF & Non-Bank Financial Institutions \\
\hline NBFIs & Nondeliverable forwards \\
\hline NDFs & Nonperforming loans \\
\hline NPLs & $\begin{array}{l}\text { Superintendency of Pension Fund Administrators } \\
\text { (Superintendencia de Administradoras de Fondos de } \\
\text { Pensiones }\end{array}$ \\
\hline SAFP & $\begin{array}{l}\text { Superintendency of Banks and Financial Institutions } \\
\text { Insurance (Superintendencia de Bancos e } \\
\text { Instituciones Financieras) }\end{array}$ \\
\hline Small and medium enterprises \\
\hline SBIF & Self-regulatory organizations \\
\hline SMEs & $\begin{array}{l}\text { Superintendency of Securities and Insurance } \\
\text { (Superintendencia de Valores y Seguros) }\end{array}$ \\
\hline SROs & $\begin{array}{l}\text { A unit of account linked to the CPI (Unidad de } \\
\text { Fomento) }\end{array}$ \\
\hline SVS & $\begin{array}{l}\text { Con } \\
\text { UF }\end{array}$ \\
\hline
\end{tabular}




\section{Overall ASSESSMent}

1. Chile's financial system is large and well diversified. Following the reform of the pension system in the early 1980s, mandatory private pension funds (AFPs) have grown at a particularly remarkable rate, pulling in their wake most of the financial system, including banks (which have benefited from large deposits by AFPs), the life insurance sector (mainly through annuities), the mortgage industry, and, more recently, commercial paper and corporate bonds. Together, AFPs and insurance companies hold a substantial fraction of total bank deposits, public securities, corporate and mortgage bonds, and Chile's external assets. Other remarkable features include low dollarization, relatively long bond maturities, large corporate external liabilities, and large private assets abroad. The equity market is also large by Latin American standards, yet illiquid, perhaps reflecting (at least in part) a concentrated distribution of wealth and income.

2. The financial system was found to be sound, overall, and resilient to shocks. The banking system weathered well the economic downturn that followed the external shocks of the late 1990s. Notwithstanding a moderate increase in delinquent loans and a substantial contraction of credit, particularly to the smaller enterprises, the system has remained profitable and well capitalized. Its vulnerability to macroeconomic shocks, within a range consistent with recently observed volatilities, was found to be moderate. The main note of caution concerns the insurance sector, for which heightened competition, some underprovisioning of risks, and weaknesses in the resolution framework will require a welldesigned road map to gradually increase its capital and shift to risk-based management and supervision.

3. Chile's exposure to external shocks is reduced under the current policy environment and increasing international financial integration. Notwithstanding a substantial diversification during the last decade, export concentration remains high and fluctuations in copper prices may continue to have a significant impact on economic activity. At the same time a repeat of the late 1990s capital account shocks cannot be fully ruled out. Yet, the impact of these shocks is expected to be much lower in the current policy environment of full fledged inflation targeting and floating exchange rate. Chile's exposure to currency fluctuations is also likely to decline as it becomes better hedged and financially more integrated with the rest of the world. However, to ensure the BCCh's capacity to implement an effective monetary policy under a broad range of macroeconomic conditions, its financial accounts would need strengthening.

\section{Further development of financial markets would improve efficiency and} resilience to future shocks. To help generate the productivity growth needed to support a new phase of rapid output growth, the financial system will need to ensure an efficient and sound allocation of resources. This will require that: (i) distribution channels for the funding now concentrated in AFPs be broadened and diversified; (ii) gaps in market infrastructure, which limit market liquidity and development, be filled; and (iii) the oversight framework be adapted to meet the needs of an increasingly integrated and complex financial system. These areas interact and reinforce each other. Illiquid and, in some cases, insufficiently transparent 
markets hinder the efficient dispersion of funds, while the excessive concentration of funds in AFPs, combined with strict investment restrictions, exacerbates the lack of market liquidity. The reform agenda should therefore address all three areas simultaneously.

\section{Greater competition in financial services will be key in facilitating a broader} allocation of investable funds. The concentration of funding in six AFPs, coupled with a still insufficient range of financing vehicles and products, including derivatives, tends to segment access to the capital market. By on-lending AFP funds, banks are helping bridge the gaps between AFPs and smaller firms but they do so at relatively high interest margins. Mutual funds and factoring and leasing companies are also helping bridge these gaps, but their role, while growing, is still marginal. Reforms in the pensions sector can help in this regard. There is room for a judicious relaxation of the overly complex and rigid investment regime without undermining AFPs' fiduciary function. At the same time, the current efforts at gradually enhancing competition should be intensified. The authorities should also prepare a contingent, more radical reform strategy, by unbundling pension-related services subject to economies of scale from services where price competition can thrive.

\section{The modernization of securities markets infrastructure is key to enhancing}

liquidity. Secondary market liquidity lags that in comparable countries, particularly in equity and corporate debt markets. Liquidity is limited by structural factors (including high concentration and the small size of the economy) and shortfalls in market infrastructure. In particular, concepts that are central to securities clearance and settlement (finality, novation, netting) must be embedded more firmly in the law, a market for securities lending and borrowing organized, conditions for the eventual introduction of multilateral netting arrangements established, OTC price reporting and disclosure enhanced, valuation methods improved, contracts and instruments standardized, and the system of market makers suitably formalized. A review of financial sector taxation is also needed, as well as a program to adopt international financial reporting standards for listed corporations after a well-designed transition period.

\section{Reforms to the currently segmented financial system oversight are required to} enhance efficiency and risk management. The segregation of supervisory responsibility by type of entity among three agencies has functioned well so far. However, as competition intensifies and boundaries between financial sectors blur, the pitfalls of this approach are increasingly surfacing. This includes gaps in market transparency and surveillance (particularly in the thriving yet opaque OTC market), shortcomings in cross-sectoral and systemic analysis coupled with weaknesses in information systems, undue scope for regulatory arbitrage, and statutory obstacles to fully consolidated supervision of financial conglomerates. Reforms should focus, in the short-term, on enhancing cooperation among regulators and filling the gaps in information, analysis, and market surveillance. Existing coordinating bodies can be strengthened and supported by a permanent technical secretariat. For the medium term, legal changes will be needed to support consolidated supervision. This should be accompanied by further progress from rule-based to risk-based supervision, a strengthening of the financial and legal autonomy of the supervisory agencies, and enhanced accountability. 
8. The main FSAP recommendations are summarized in Box 1. Some of the recommendations are addressed, totally or partially, in the proposed Capital Markets Reform II Law (CMII), under discussion at this time of writing. Some reforms can proceed in parallel, within a coherent plan that sets out priorities, identifies complementarities, allocates institutional responsibilities, provides for coordination mechanisms, and establishes suitable timetables. While recommendations are often classified as "medium term" because they would require legal changes, this does not necessarily imply that they have lower priority. ${ }^{1}$

\begin{tabular}{|c|c|c|c|}
\hline \multicolumn{4}{|c|}{ Box 1. Summary of FSAP Recommendations } \\
\hline & $\begin{array}{l}\text { Short } \\
\text { Term }\end{array}$ & $\begin{array}{c}\text { Medium } \\
\text { Term }\end{array}$ & $\begin{array}{l}\text { Already } \\
\text { in CMII }\end{array}$ \\
\hline \multicolumn{4}{|l|}{ A. Central Bank } \\
\hline Strengthen BCCh's financial accounts. & & $\mathrm{X}$ & \\
\hline \multicolumn{4}{|l|}{ B. Commercial Banks } \\
\hline Further develop risk-based supervisory approach. & $\mathrm{X}$ & $\mathrm{X}$ & \\
\hline $\begin{array}{l}\text { Clarify SBIF's powers as regards licenses and expand 'fit and proper' } \\
\text { tests. }\end{array}$ & & $\mathrm{X}$ & \\
\hline Impose capital requirements for market risk. & $\mathrm{X}$ & $\mathrm{X}$ & \\
\hline Improve disclosure of risk exposure \& management practices by banks. & & $\mathrm{X}$ & \\
\hline Strengthen bank resolution regime. & & $\mathrm{X}$ & \\
\hline \multicolumn{4}{|l|}{ C. Corporate Sector } \\
\hline Reform legislation for movable collateral. & $\mathrm{X}$ & & Yes \\
\hline Create national register of pledges. & $\mathrm{X}$ & & Yes \\
\hline Improve quality of SME financial statements. & & $\mathrm{X}$ & \\
\hline Eliminate 'tasa máxima convencional' or introduce more flexibility. & & $\mathrm{X}$ & \\
\hline \multicolumn{4}{|l|}{ D. Insurance } \\
\hline Upgrade provisioning requirements and strengthen supervision. & $\mathrm{X}$ & & \\
\hline Strengthen insurance company failure resolution framework. & & $\mathrm{X}$ & Partially \\
\hline Shift emphasis from rules management to risk management. & $\mathrm{X}$ & $\mathrm{X}$ & \\
\hline \multicolumn{4}{|l|}{ E. AFPs } \\
\hline Judiciously relax investment regime. & $\mathrm{X}$ & & \\
\hline Move from compliance-based to risk-based supervision. & $\mathrm{X}$ & $\mathrm{X}$ & \\
\hline Encourage outsourcing and regulate service providers. & $\mathrm{X}$ & & \\
\hline Enhance attractiveness of voluntary system. & $\mathrm{X}$ & & Partially \\
\hline Develop contingent strategy to enhance competition. & & $\mathrm{X}$ & \\
\hline Reduce risks faced by workers at retirement. & & $\mathrm{X}$ & \\
\hline F. Securities Markets & & & \\
\hline
\end{tabular}

\footnotetext{
${ }^{1}$ The FSAP analysis and recommendations are supported by technical annexes dealing with: (i) bank risk management and disclosure; (ii) corporate sector; (iii) pension funds; (iv) insurance; (v) hedges; (vi) capital market liquidity; and (vii) financial conglomerates.
} 


\begin{tabular}{|c|c|c|c|}
\hline Embed concepts of finality, netting, and novation in the law. & $\mathrm{X}$ & & Partially \\
\hline Promote industry-financed fund for multilateral netting. & $\mathrm{X}$ & $\mathrm{X}$ & \\
\hline Organize securities lending and borrowing. & $\mathrm{X}$ & & \\
\hline $\begin{array}{l}\text { Establish price reporting for OTC trades and harmonize securities } \\
\text { valuation. }\end{array}$ & $\mathrm{X}$ & & \\
\hline Introduce international standard contract for repos and derivatives. & $\mathrm{X}$ & & \\
\hline Enhance standardization of financial instruments. & & $\mathrm{X}$ & \\
\hline Suitably formalize market-makers for public debt. & $\mathrm{X}$ & & \\
\hline Increase SVS's budgetary and staff resources. & $\mathrm{X}$ & & \\
\hline Introduce minimum standards for securities industry. & $\mathrm{X}$ & & \\
\hline Require internal compliance programs by brokerage firms. & $\mathrm{X}$ & & \\
\hline Widen SVS enforcement powers. & & $\mathrm{X}$ & Partially \\
\hline $\begin{array}{l}\text { Give SVS power to appoint a conservator or liquidator for brokerage } \\
\text { firms. }\end{array}$ & $\mathrm{X}$ & & \\
\hline Implement risk based supervision. & $\mathrm{X}$ & $\mathrm{X}$ & \\
\hline \multicolumn{4}{|l|}{ G. Taxation, Financial Reporting Standards, Corporate Governance } \\
\hline Review financial sector taxation. & $\mathrm{X}$ & $\mathrm{X}$ & Partially \\
\hline Strengthen financial reporting regime for listed companies. & & $\mathrm{X}$ & \\
\hline Enhance corporate governance, including training of directors and judges. & $\mathrm{X}$ & & \\
\hline \multicolumn{4}{|l|}{ H. Hedges } \\
\hline Correct deficiencies in information and market infrastructure. & $\mathrm{X}$ & $\mathrm{X}$ & \\
\hline Relax restrictions on short selling, writing and trading. & & $\mathrm{X}$ & \\
\hline \multicolumn{4}{|l|}{ I. Other Financing Vehicles } \\
\hline Support development of "bridging" vehicles. & & $\mathrm{X}$ & Partially \\
\hline \multicolumn{4}{|l|}{ J. Cross-Sectoral Financial Oversight } \\
\hline Embed Committee of Superintendents in the law. & $\mathrm{X}$ & & Yes \\
\hline Establish MOUs and technical secretariat for coordinating committees. & $\mathrm{X}$ & & \\
\hline Introduce regular staff exchanges. & $\mathrm{X}$ & & \\
\hline Introduce fully consolidated supervision and relax firewalls. & & $\mathrm{X}$ & \\
\hline $\begin{array}{l}\text { Resolve conflicts of competence and draw contingency plans for failure of } \\
\text { financial conglomerates. }\end{array}$ & $\mathrm{X}$ & $\mathrm{X}$ & \\
\hline Strengthen the information system. & $\mathrm{X}$ & & \\
\hline Clarify and strengthen legal protection of supervisors. & & $\mathrm{X}$ & \\
\hline Allow supervisors control over budget with appropriate accountability. & & $\mathrm{X}$ & \\
\hline Disconnect timing of Superintendents' appointments from political cycle. & & $\mathrm{X}$ & \\
\hline \multicolumn{4}{|l|}{ K. Anti-Money Laundering } \\
\hline Strengthen capacity to monitor compliance. & $\mathrm{X}$ & & \\
\hline Enhance monitoring of securities, insurance, and FX operators. & $\mathrm{X}$ & & \\
\hline Improve mutual assistance and international cooperation in freezing assets. & $\mathrm{X}$ & & \\
\hline
\end{tabular}




\section{Financial Structure ANd MaCroeconomic ENVIronMent}

\section{A. Overview of the Financial System}

\section{The Chilean financial}

sector is large, diversified, and

increasingly integrated

Financial Sector Size Across Countries with the rest of the world. It has showed remarkable growth throughout the last two decades and is now the largest (in assets to GDP) and among the deepest in the region (Appendix, Tables 1 and 2). The core of the system are the banking sector and the mandatory, privatelyadministered, pension system. The latter is one of the largest in the world (only 8 OECD countries have comparable pension assets). The insurance sector (mainly annuities), the equity market, the corporate bond market, and

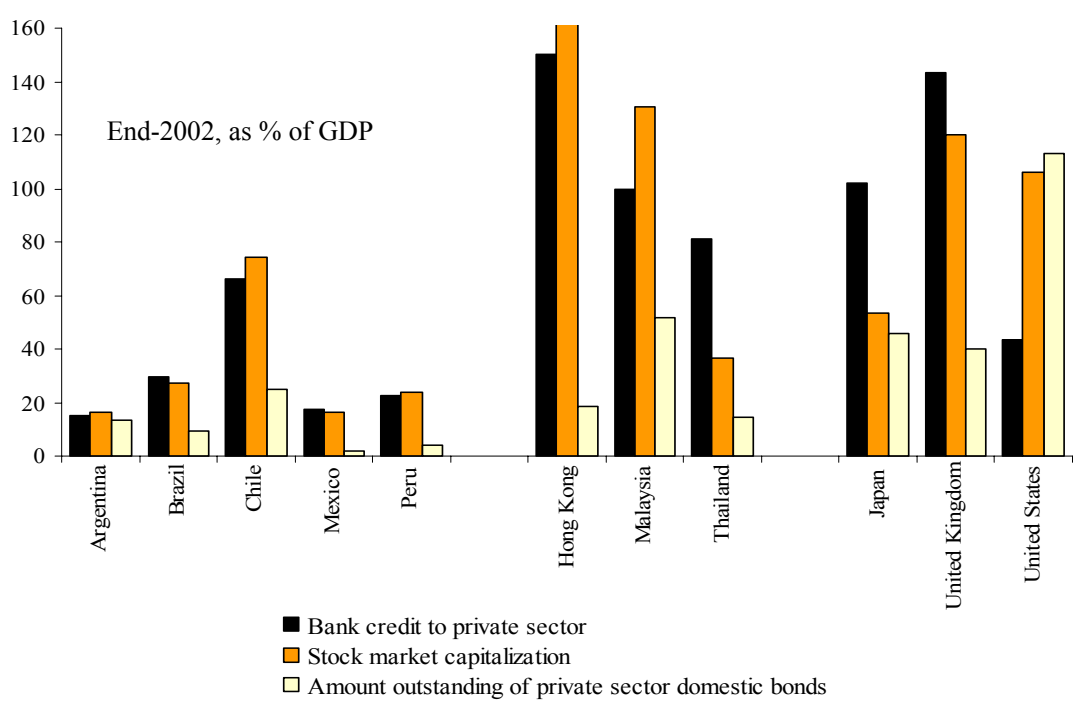

Sources: International Financial Statistics (IFS), IFC's Emerging Markets Data Base, World Federation of Exchanges (FIBV), Bank of International Settlements (BIS), and The World Bank. the mortgage market are also large by regional standards. The corporate bond and mortgage markets have grown rapidly during recent years and so have the markets for commercial paper, albeit from a lower base. The mutual fund industry and the nonbank finance sector, while also growing rapidly, remain relatively small. The domestic public debt market is moderate in size and mostly concentrated in instruments issued by the BCCh. Other noteworthy features of Chile's financial system include relatively long maturities (reflecting the widespread use of priceindexed instruments), large external liabilities (mostly of the corporate sector), and large external assets. The latter grew rapidly in recent years as AFPs were allowed to invest abroad a rising share of their portfolio.

10. The development of the financial system is closely linked to the growth of private pension funds. The large size of Chile's pension sector is the result of the switch (in 1981) from a public pay-as-you-go system of predefined benefits to a defined-contribution system of fully-funded, privately managed, individual accounts. The new system has created a significant demand for investment assets and has helped develop capital markets. Together with the life insurance companies, whose growth is mainly derived from that of the pension funds, AFPs hold a substantial fraction of total bank deposits, public sector debt securities, corporate and mortgage bonds, and, more recently, Chile's external assets. Projections suggest that institutional investors will become larger than the banking sector in the next two 
decades, further increasing Chile: Size and Composition of Private Sector Savings their systemic importance. This increasing dominance partly reflects the fact that the bulk of household savings is channeled into the compulsory (Pillar II) component of the pension system. Household savings excluding mandatory pension contributions are small and corporate savings account for a large part of private savings. The high concentration of savings contributes to explain a very limited retail investors base.

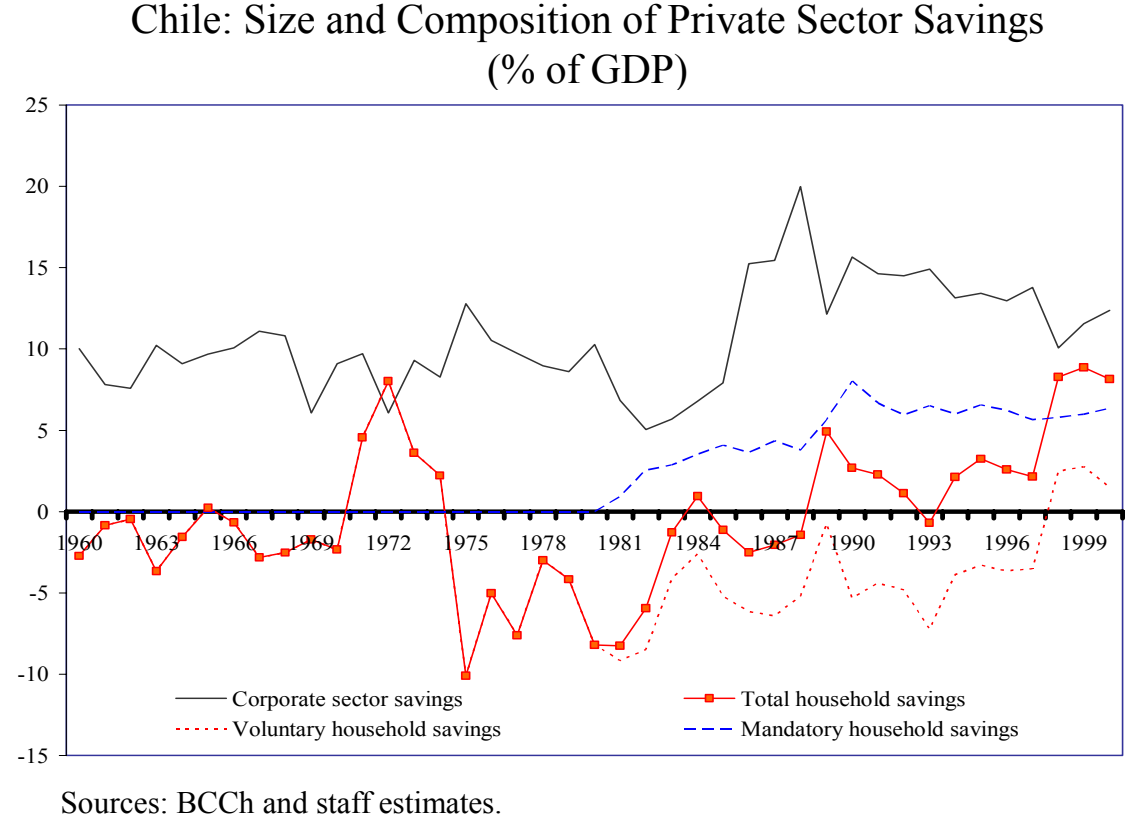

Chile: National Balance Sheet ${ }^{1 /}$

Financial Assets/Liabilities by Sector as a \% of GDP, Dec-2003 (unless otherwise specified)

\begin{tabular}{|c|c|c|c|c|c|c|c|c|c|}
\hline Liabilities of: & Households & Firms & $\begin{array}{l}\text { Public } \\
\text { Sector }\end{array}$ & $\begin{array}{l}\text { External } \\
\text { Sector }^{3}\end{array}$ & Banks & AFPs & $\begin{array}{r}\text { Insurance } \\
\text { Companies }\end{array}$ & Mutual Funds & Total \\
\hline \multicolumn{10}{|l|}{ Assets of: } \\
\hline Households & 0.0 & 0.0 & 0.0 & 6.9 & $19.2^{2}$ & 67.8 & 1.1 & 0.0 & 94.9 \\
\hline Firms & 0.0 & 0.0 & 0.0 & $39.8^{4}$ & $18.5^{2}$ & 0.0 & 0.4 & 0.0 & 58.7 \\
\hline Public sector & 0 & 1.9 & 0.0 & 22.2 & 3.8 & 0.0 & 0.0 & 0.0 & 27.9 \\
\hline External Sector ${ }^{3}$ & 0.0 & $107.7^{5}$ & 10.5 & 0.0 & 6.6 & 0.0 & 0.0 & 0.0 & 124.8 \\
\hline Banks & $19.6^{2}$ & $40.1^{2}$ & 11.5 & 2.7 & 0.0 & 0.1 & 0.1 & 0.1 & 74.2 \\
\hline AFPs & 0.0 & 12.7 & 14.7 & 14.2 & 16.3 & 0.0 & 0.4 & 1.6 & 60.0 \\
\hline Insurance Companies & 0.1 & $5.1^{6}$ & 3.7 & 0.5 & 6.0 & 0.0 & 0.0 & 0.3 & 15.8 \\
\hline Mutual Funds & 0.0 & 2.5 & 4.1 & 0.6 & 1.5 & 0.0 & 0.0 & 0.0 & 8.7 \\
\hline Total & 19.7 & 170.0 & 44.6 & 86.9 & 71.8 & 67.8 & 2.1 & 2.0 & 465.0 \\
\hline
\end{tabular}

Source: BCCh, SBIF, SAFP, SVS, IFS and staff calculations

${ }^{1 /}$ The totals do not necessarily correspond to total asset/liabilities of each sector, as some types of assets(eg. fixed assets)and capital are not included.

2/ as of end-Sept. 2003

${ }^{3 /}$ end-2002

${ }^{4 /}$ Assumes that all direct and portfolio investment is done by firms

${ }^{5 /}$ includes FDI, which accounts for $66 \%$ of GDP

${ }^{6}$ Includes investments in AFP and insurance companies' equities as well. Separation is not possible.

\section{The financial (and real) sectors are characterized by high concentration and} conglomeration. The three largest banks account for 55 percent of bank assets, while the three largest AFPs manage 70 percent of pension fund assets. Moreover, a majority of financial institutions are controlled by a handful of financial conglomerates with significant linkages between the banking, securities, mutual and pension fund management, and insurance businesses. The high concentration in the financial sector echoes an equally high 
concentration in the

real sector, where

large nonfinancial

conglomerates

account for a

disproportionately

large fraction of

economic activity

and absorb most of

the available

financing. ${ }^{2}$ In turn,

this high

concentration, which

has adverse

implications for

liquidity in securities

markets, in part

Gini Index, various countries, 1998

reflects a high

concentration of income and wealth.

Chile: Percent of Financial Institutions Belonging to a Financial Conglomerate (2003)

\begin{tabular}{l|c|c|c|c}
\hline \multicolumn{1}{c|}{ Sector $^{1 /}$} & Banking & Securities & $\begin{array}{c}\text { Insurance } \\
\text { (life and nonlife) }\end{array}$ & Pensions $^{2 /}$ \\
\hline Total $^{3 /}$ & 98 & 91 & 40 & 98 \\
Foreign conglomerate & 41 & 47 & 13 & 80 \\
'Pure' domestic conglomerate & 34 & 23 & 9 & 2 \\
Mixed activities domestic conglomerate & 23 & 21 & 18 & 16 \\
\hline
\end{tabular}

Sources: SBIF, SVS, SAFP, and staff calculations.

1/ Percentages are based on bank assets (banking), securities turnover by stock brokerage companies/corredores de bolsa (securities), direct premiums (insurance) and AFP assets under management (pensions) for 2003.

2/ AFP Habitat is assumed to be controlled by Citibank even though it is jointly owned with the Chilean Chamber of Construction.

3/ Domestic and foreign groups that are only active in one Chilean financial sector are not considered financial conglomerates.

\footnotetext{
${ }^{2}$ One percent of firms account for 78 percent of sales by enterprises and absorb 79 percent of domestic bank financing and virtually all financing through the capital market.
} 
Chile: Distribution of Firms by Size, Sales, Exports, and Employment ${ }^{1 /}$

\begin{tabular}{|c|c|c|c|c|c|c|c|c|}
\hline \multirow[t]{2}{*}{ Firms } & \multicolumn{2}{|c|}{ Number } & \multicolumn{2}{|c|}{ Sales } & \multicolumn{2}{|c|}{ Export } & \multicolumn{2}{|c|}{ Employment } \\
\hline & Thousands & $\%$ & US\$ billion & $\%$ & US\$ million & $\%$ & Thousands & $\%$ \\
\hline Micro ${ }^{2 /}$ & 535 & 82 & 7 & 3 & 14 & 0 & 2,124 & 50 \\
\hline Small $^{3 /}$ & 96 & 15 & 20 & 9 & 176 & 1 & 845 & 20 \\
\hline Medium $^{4 /}$ & 13 & 2 & 19 & 9 & 527 & 3 & 539 & 13 \\
\hline Large $^{5 /}$ & 6 & 1 & 164 & 78 & 17,477 & 96 & 713 & 17 \\
\hline Total & 650 & 100 & 210 & 100 & 18,194 & 100 & 4,221 & 100 \\
\hline
\end{tabular}

Source: Government of Chile.

1/ Data are for 2001, except for exports (2000).

2/ Sales below US\$ 68,688.

3/ Sales between US\$ 700,000 and US\$ 68,688.

4/ Sales between US\$2.8 million and US\$17.2 million.

5/ Sales above US\$ 17.2 million.

\section{B. Macroeconomic Environment}

12. Chile's strong macroeconomic performance and financial development have been supported by a sound macroeconomic management and an impressive agenda of reforms. Boosted by strong productivity gains, average annual real GDP growth rates exceeded 5 percent during 19902003, resulting in a doubling of per capita income. This was supported by a steady monetary stabilization to low single digit inflation rates, a long record of prudent fiscal management (consolidated into a structural fiscal balance target rule in 2000), and a comprehensive and far reaching program of structural reforms. In the financial area, in addition to the already cited pension reform, other key initiatives included: (i) the consistent promotion of price-indexed financial instruments, which, together with the build up of monetary policy credibility, resulted in a low level of dollarization; (ii) the introduction of comprehensive capital market reforms (the 2001 Capital Markets I law, followed by the draft CMII law); and (iii) a recent review of monetary and public debt management practices (which "nominalized" the conduct of monetary policy and rationalized the issuance of public debt instruments). Chile's economic performance and financial development was supported by well-functioning institutions, 
including in the legal and political realms, placing it well above the regional average in terms of reliability and security of the rule of law and property rights. ${ }^{3}$

13. Despite its sound macroeconomic framework, Chile was not immune to the regional financial turmoil during the late 1990s. Chile's rapid output growth of the 1990s was accompanied by substantial current account deficits, as domestic saving rates remained moderate. The dependence on foreign savings increased Chile's vulnerability to the international and regional turbulences of the late 1990s. While Chile weathered the storm much better than most of the neighboring countries, output and credit growth decelerated sharply as the current account deficit swung from a large deficit into a small surplus (Appendix, Table 1). The contraction of credit was particularly strong for the smaller enterprises. Output growth has started to recover only recently, stimulated by a favorable external
Savings and Investment, various countries

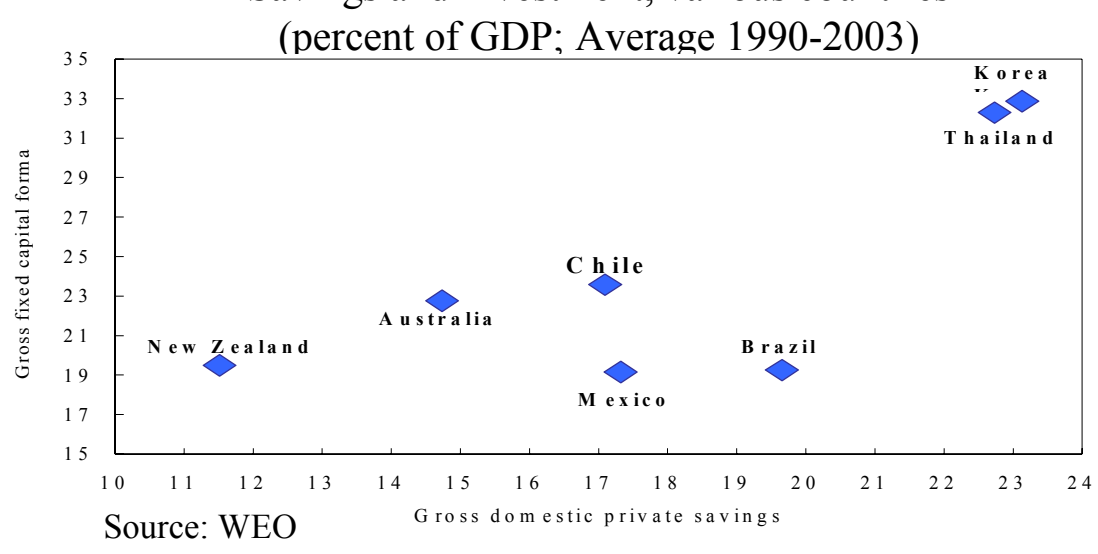

Chile: Current Account Deficit (percentage of GDP)

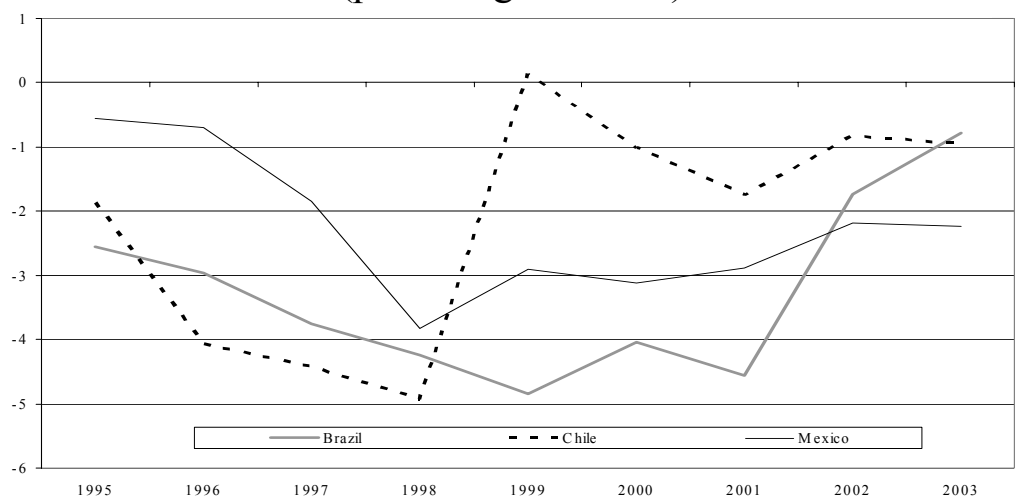

Source: IFS.

Corporate Lending by Banks (average annual growth rate, 2001-03)

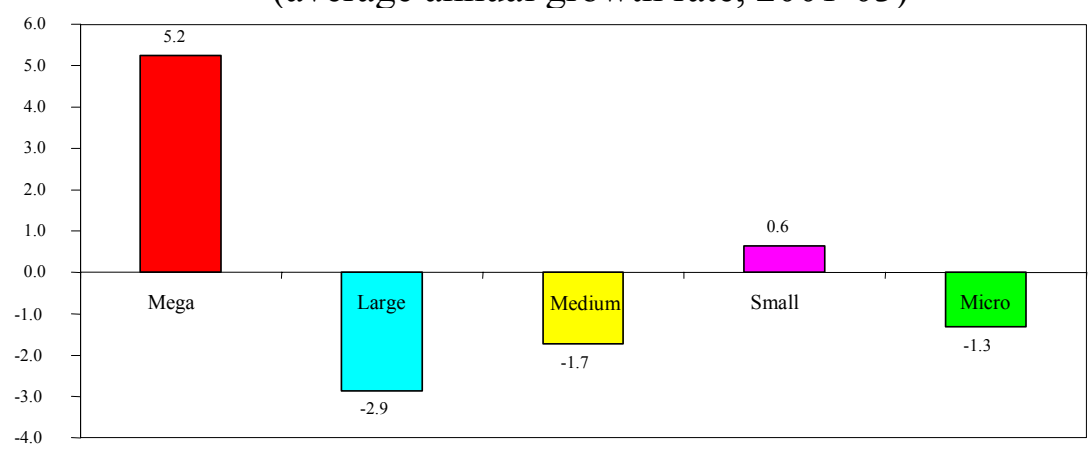

Source: SBIF.

${ }^{3}$ Chile was ranked in the $9^{\text {th }}$ decile, together with Hong Kong and the U.S., in the 2000/2001 index of the "rule of law" (Kaufmann et al., 2002). 
environment, a notable strengthening of copper prices, and a supportive monetary policy. Output growth is expected to reach around 5 percent in 2004.

\section{Macro-Financial Stability Analysis}

14. Chile remains exposed to real external shocks. Notwithstanding a substantial diversification during the last decade, export concentration remains high, with copper accounting for 36 percent of total exports in the last four years. While the Copper Stabilization Fund $(\mathrm{CSF})^{4}$ and the structural fiscal balance rule should help mitigate the fiscal impact of terms of trade shocks, the correlation between

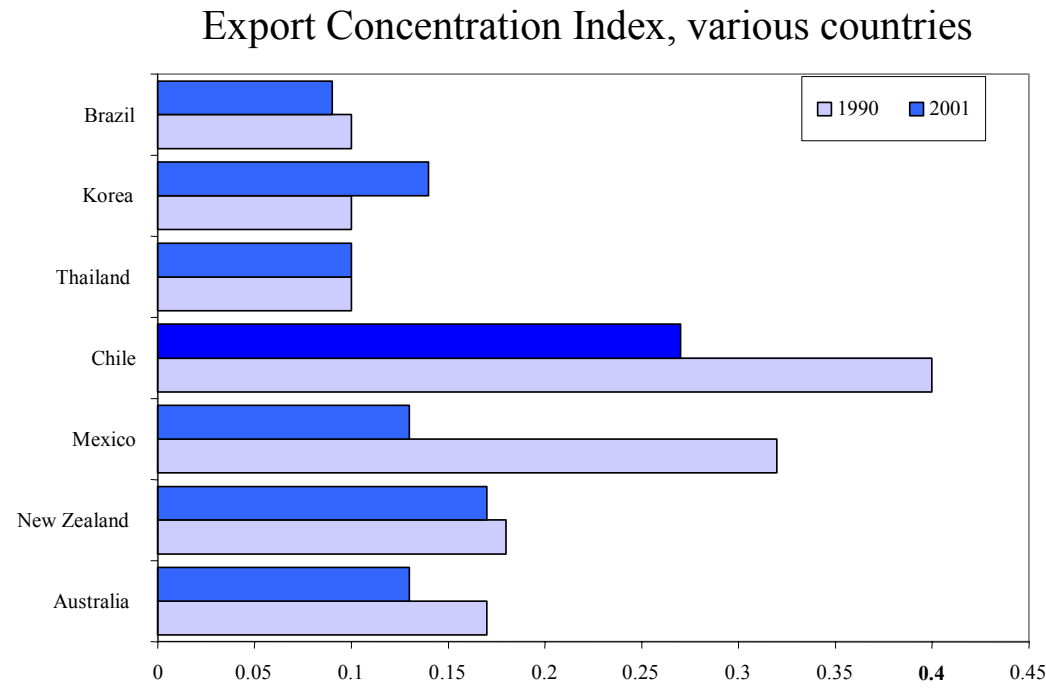

Source: UNCTAD. copper prices and the business cycle has been strong historically and could continue to be significant in the foreseeable future. In particular, investment, the exchange rate, and capital inflows could remain sensitive to changes in copper prices, contributing to macroeconomic volatility and potential banking system vulnerabilities. Stress tests ${ }^{5}$ indicate that, while a 10 percent adverse terms of trade shock would have only a marginal impact on banks' solvency, it could nonetheless result in some liquidity tensions if it induces AFPs and other large depositors to reallocate their deposits across banks. ${ }^{6}$

\footnotetext{
${ }^{4}$ The CSF (established in 1985) receives transfers from CODELCO when copper prices are high. Funds can be withdrawn by the government when prices decline.

${ }^{5}$ Bank-by-bank stress tests were designed and conducted by a working group that included BCCh, SBIF and Fund staff.

${ }^{6}$ Most banks have a high share of illiquid assets financed with potentially volatile liabilities.
} 
Chilean Banking System: Stress Tests for Market and Credit Risk

\begin{tabular}{|c|c|c|c|c|}
\hline \multirow{3}{*}{$\begin{array}{l}\text { Variables } \\
\text { Stressed } 1 /\end{array}$} & \multicolumn{4}{|c|}{ Outcome } \\
\hline & \multicolumn{2}{|c|}{ Banks with CAR $<8 \%$} & \multicolumn{2}{|c|}{ Banks with CAR $<10,>8 \%$} \\
\hline & \# of banks & $\%$ of system assets & \# of banks & $\%$ of system assets \\
\hline \multicolumn{5}{|l|}{ Exchange rate } \\
\hline $25 \%$ depreciation, direct effect $2 /$ & 0 & 0 & 0 & 0 \\
\hline $25 \%$ depreciation, direct and indirect effect $3 /$ & 1 & $<1$ & 6 & 34 \\
\hline $7 \%$ apreciation, direct effect $2 /$ & 0 & 0 & 0 & 0 \\
\hline \multicolumn{5}{|l|}{ Intererest rate } \\
\hline Parallel decrease, domestic 160 bp., USD rate 100 bp. & 0 & 0 & 0 & 0 \\
\hline Parallel increse, domestic 160 bp., USD rate $100 \mathrm{bp}$. & 0 & 0 & 0 & 0 \\
\hline Increase and shift in yield curve & 0 & 0 & 0 & 0 \\
\hline \multicolumn{5}{|l|}{ Credit Quality } \\
\hline Increase in provisions equal to that during 1998 & 0 & 0 & 2 & $<1$ \\
\hline $5 \%$ reduction in firms' operating margin $4 /$ & 4 & 21 & 5 & 25 \\
\hline Scenario Analysis: $10 \%$ decrease in TOT $5 /$ & 0 & 0 & 3 & 25 \\
\hline
\end{tabular}

Source: Staff estimates.

1/ Size of the shocks to the exchange rate, interest rate, and TOT assume normality of the distribution of the rates of change under a $99 \%$ confidence interval. In no case was the shock observed since 1998 greater than the shocks applied.

2/ Refers to the gains/losses incurred on the banks' net position.

3/ Includes impact on banks' credit quality.

4/ Analysis based on balance sheet and P\&L information of corporates registered with SVS

5/ The nature and size of the shocks under the scenario analysis was determined by the BCCH's macro model: Shocks include increases in: (i) short term nom. rate of 180 bp.; (ii) short term real rate of 35 bp.; (iii) long term nom. rate of $160 \mathrm{bp}$.; (iv) long term real rate of 11 bp.; (v) and unemployment of 4 percentage points $+8.4 \%$ depreciation and a decrease in GDP of 1.1 percentage points.

15. Chile's exposure to capital account shocks cannot be dismissed but its vulnerability is much diminished in the current monetary policy environment.

Notwithstanding Chile's record of low and fairly stable sovereign spreads, a repeat of the late $1990 \mathrm{~s}$ capital outflows cannot be totally ruled out. Yet, the severity of the 1998-1999 current account reversal was largely exacerbated by a domestic portfolio reshuffling (away from dollar liabilities and towards dollar assets)
EMBI Global Sovereign Spreads, various countries

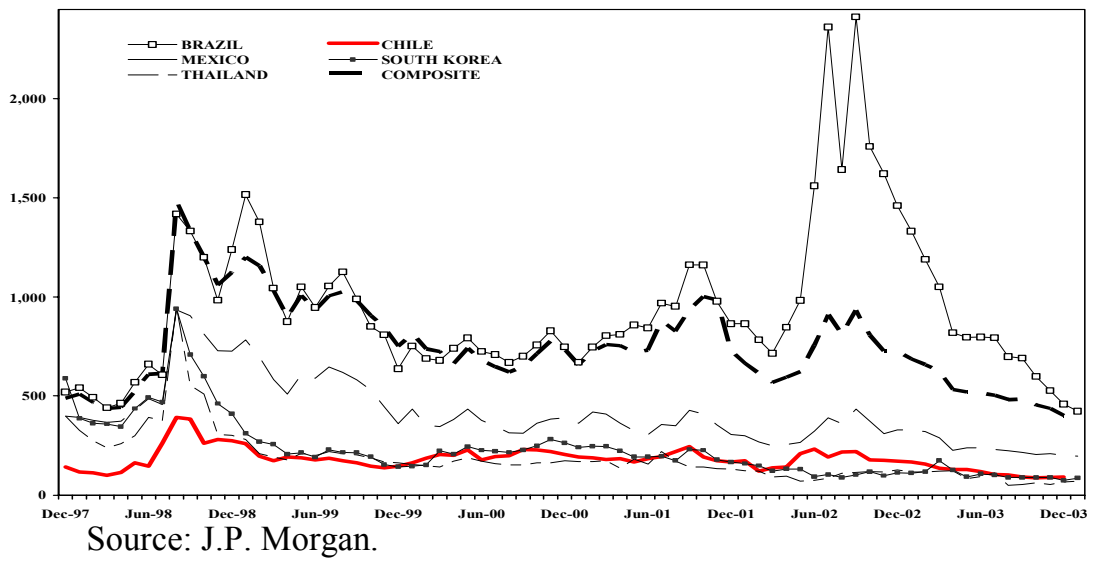

Chile: Local and International Corporate Bond Issues

(Equivalent in Million US\$)

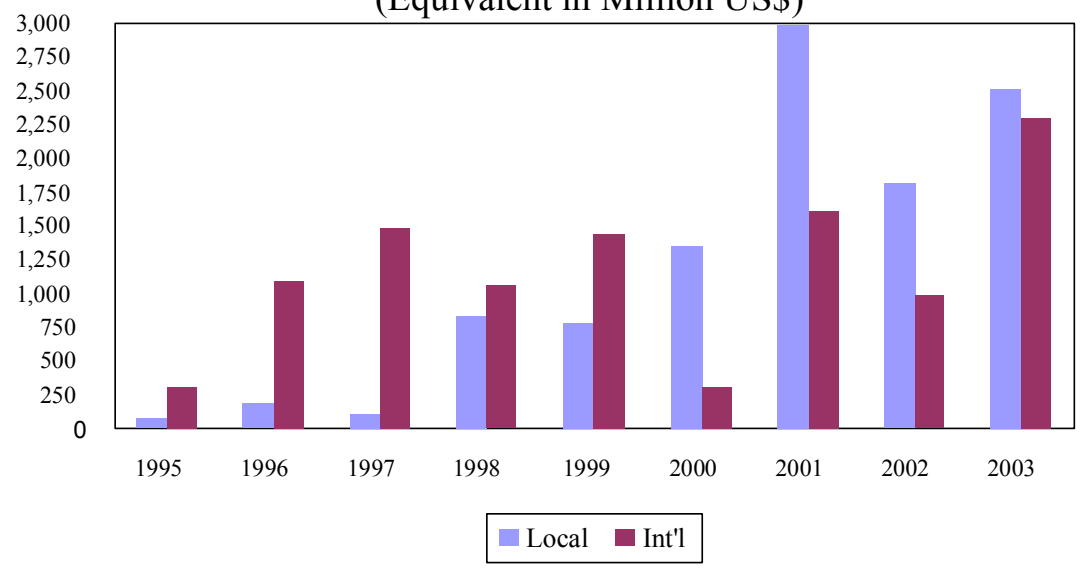

Sources: SVS, Larrain Vial Brokerage, Bloomberg, Bondware, Euromoney. 
resulting from the liberalization of the capital account and the elimination of the foreign exchange band, rather than a loss of access to international capital markets. ${ }^{7}$ The new policy environment of full-fledged inflation targeting, floating exchange rate, and strong fiscal rule, is significantly more resilient to shocks. It should limit the risk of sharp policy discontinuities while enhancing the scope for countercyclical policies.

Chile: Differential between Domestic Lending Rates and US Prime Rate

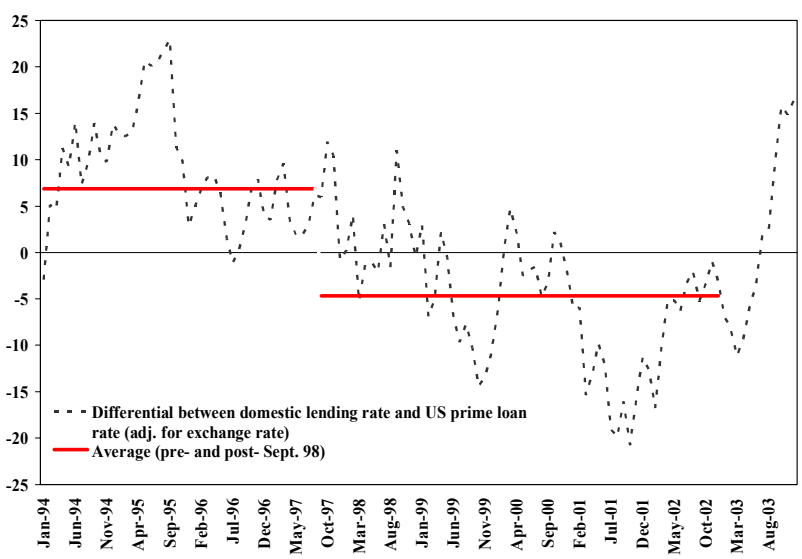

Sources: BCCh and staff estimates.

\section{Chile: Indicators of Uncertainty}

Forward bid-offer spreads (\%)

Net Forward Position of Banks (mn. CH\$)

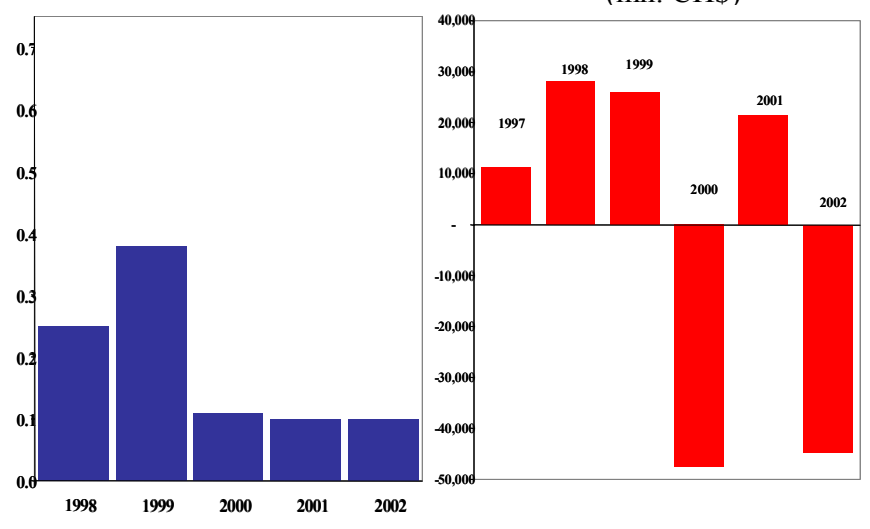

Source: BCCh.

\section{The rising financial} integration with the rest of the world should increase the resilience of the system to capital account shocks. Chile's financial integration with the rest of the world is high compared to most emerging economies. It expanded rapidly in recent years, reflecting in part the strong increase in AFPs' foreign assets and the 1998 liberalization of the
Chile: Financial Integration

(Assets and Liabilities/GDP)

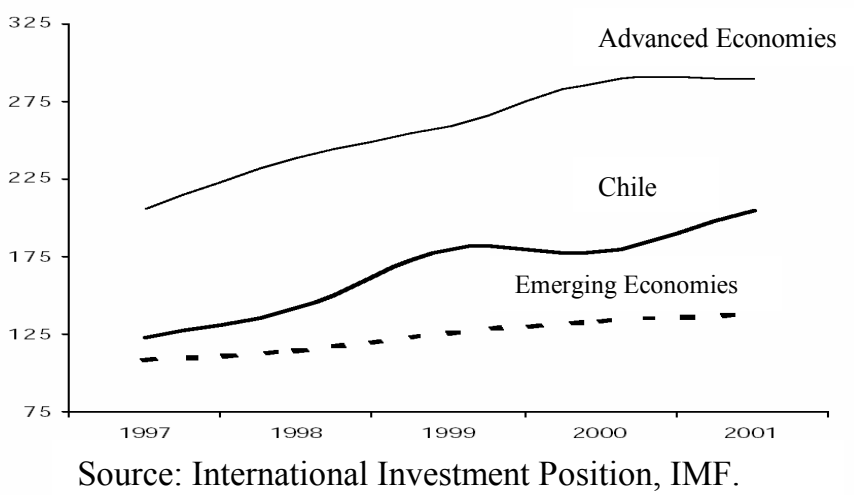

${ }^{7}$ There was a shift in relative costs in favor of the peso, partly due to the removal of the interest rate wedge associated with reserve requirements on capital inflows. This was compounded by shifts in uncertainty as investors, concerned about the sustainability of the exchange rate band and, later, by its elimination, fled to dollar assets abroad while debtors moved away from dollar obligations due to the increased volatility of dollar rates (the variance of the exchange rate increased three-fold after it was allowed to float freely). The increase in exchange rate uncertainty during 1997-1999 is apparent in the increased bid-ask spreads and the surge in demand for currency hedges by dollar-indebted bank customers. 
capital account. ${ }^{8}$ This should help limit Chile's exposure to the risk of sudden stops.

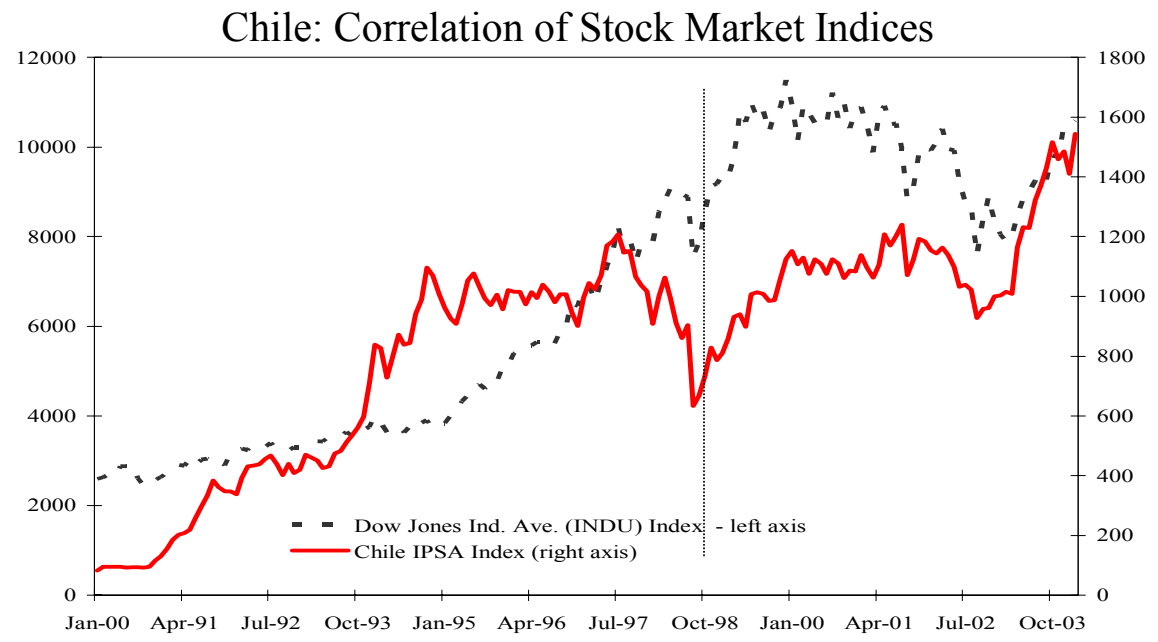

Source: Datastream.

17. Banks' exposure to currency risk is limited. The floating exchange rate has encouraged better risk management among corporates and led to a marked increase in foreign exchange hedges, limiting their exposure to exchange rate volatility. About 40 percent of corporate foreign debt is estimated to be currently hedged. Partly as a result, banks' indirect exposure to currency risk (through the credit risk associated with dollar indebted corporates), while significant, was found to be manageable (see Stress Tests for Market and Credit Risk table). ${ }^{9}$ Due to their small open positions, banks' direct exposure to currency risk is negligible.

\footnotetext{
${ }^{8}$ The large recent increase in the comovements of returns between the local and international equity markets (the correlation of stock market indices rose from 0.36 before 1998 to 0.58 after 1998) is consistent with increased financial integration.

${ }^{9}$ Nearly 60 percent of corporate debt is denominated in US dollars. Out of the 50 firms with the largest currency exposure (accounting for 89 percent of total US dollar debt and 64 percent of corporate debt to domestic banks),
}

(continued...) 
Chile: Stress Test on Currencv Risk in Cornorates

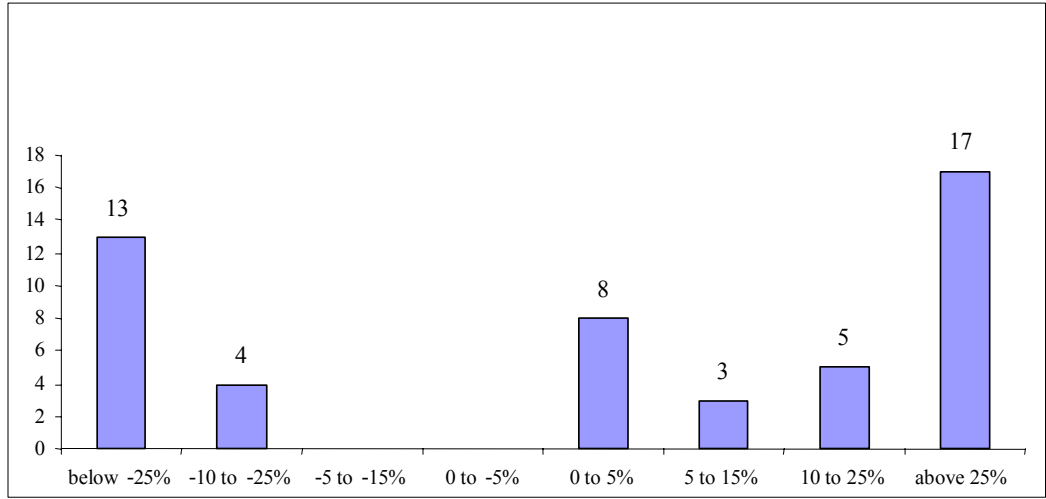

Sources: FECUS and staff estimates.

18. The BCCh's financial accounts need strengthening. With the current low inflation target, the inflation tax on the money base does not cover the BCCh's operating expenditures and the carrying cost of its debt-financed Chile: BCCh Summary Balance Sheet, End 2003

foreign and domestic assets. ${ }^{10}$ The central bank's weak financial accounts could constrain the implementation of monetary policy. While the BCCh's profitability could be improved by downsizing its balance sheet (in particular, the carrying cost of claims on government will disappear once this debt is repaid), the scope for doing so is limited in view of the need for maintaining minimum levels of international reserves and domestic

(In billions of US dollars)

\begin{tabular}{lc|lc}
\hline Liabilities & & Assets & \\
\hline Monetary base & 3.0 & International Reserves & 18.0 \\
Currency & $(2.0)$ & & \\
Bank Reserves & $(1.0)$ & & \\
BCCh debt & 23.0 & BCCh claims on government & 5.0 \\
Capital & -3.0 & & \\
Total & 23.0 & Total & 23.0 \\
\hline
\end{tabular}

Source: $\mathrm{BCCh}$ and staff calculations.

Chile: BCCh Structural Income Statement (In millions of US dollars)

\begin{tabular}{lrr}
\hline Revenues & $\underline{90}$ \\
\hline Inflation tax on monetary base (3\% inflation) & $3 \times 0.03$ & $\underline{364}$ \\
Expenditures & $16 \times 0.0014$ & 224 \\
\hline Carrying cost of NIR (140 basis points) ${ }^{1 /}$ & $5 \times 0.0019$ & 95 \\
Carrying cost of claims on government (190 basis points) ${ }^{2 /}$ & 50 \\
Operating expenditures & -274 \\
Changes in real net worth: & $-274 / 73,000$ & $\underline{-0.37}$ \\
\hline Memorandum Item & \\
$\quad$ Net losses as a fraction of GDP & \\
\hline Source: BCCh and staff calculations. & \\
& \\
${ }^{1 /}$ Calculated as Chile's country risk (90 basis points as of Chile EMBIG's spread of March 4, 2004) \\
plus a premium for currency risk and the duration mismatch between debt and international reserves \\
(50 basis points). \\
${ }^{2 /}$ Calculated as the country risk plus the excess average yield of international reserves during 2003 \\
over the yield of BCCh's claims on government during the same period (Libor plus 50 basis points).
\end{tabular}

seven would incur debt servicing difficulties under a one-year real exchange rate depreciation of 25 percent. The number of firms in difficulty could increase if the impact of the depreciation is compounded by adverse changes in other macro variables.

${ }^{10}$ The weak financial accounts of the BCCh reflect large central bank supports to banks in the 1980s and repeated sterilized exchange market interventions during part of the 1990s (see IMF Country Reports $\mathrm{N}^{\circ}$ 03/303 and $03 / 312$ ). 
public debt. ${ }^{11}$ Addressing this issue will require recapitalizing the $\mathrm{BCCh}$ and preferably transferring at least some of its debt to the government.

\section{BANKING}

\section{The Chilean banking system is financially strong, well regulated and} supervised, and internationally integrated. The banking system is one of the deepest and most developed in the region and among emerging economies, with total assets of US\$ 68 billion at end-2003, equivalent to 96 percent of GDP. It is well capitalized (the capital ratio exceeds 14 percent) and highly profitable. The ratio of nonperforming loans to total loans is low, at 2 percent. ${ }^{12}$ Bank oversight is strong, but will need to adapt in some areas.

20. The banking sector is

concentrated

following a rapid pace of consolidation.

The relatively small number of banks $(26$ at end 2003, down from 40 in 1992) reflects the 1982-83 banking crisis and a wave of recent mergers. However, following a lowering of minimum capital requirements in 2001 , there was a wave of niche entrants.

Nineteen banks are privately owned and one (the third largest) is state-owned. Six banks (40 percent of system assets) are majority owned or controlled by foreign banks. Banking concentration, as measured by the market share of the three or five largest banks, is high.

21. Chilean banks are resilient and profitable. Their historically high profitability was driven by comfortable interest margins, in turn partly a reflection of low (albeit rising) fee incomes (Appendix, Table 3). Profitability remained high in recent years notwithstanding

\footnotetext{
${ }^{11}$ A deep and liquid market for domestic public debt is needed to sustain a reliable yield curve and provide collateral for the payments system.

${ }^{12}$ However, if measured under U.S. GAAP, the ratio would double (Chilean norms require that only the pastdue portion of delinquent loans be classified as past-due).
} 
some deterioration of asset quality following the 1998-2001 economic slowdown. Stress tests indicate that the banking system would only be moderately affected by further shocks affecting market risk or credit risk (see Stress Test for Market and Credit Risk table). Banks' operating efficiency is good by regional standards, albeit lags somewhat behind that of the fastest growing emerging economies.

Commercial Banks’ Net Interest Margin, 2002

(various countries)

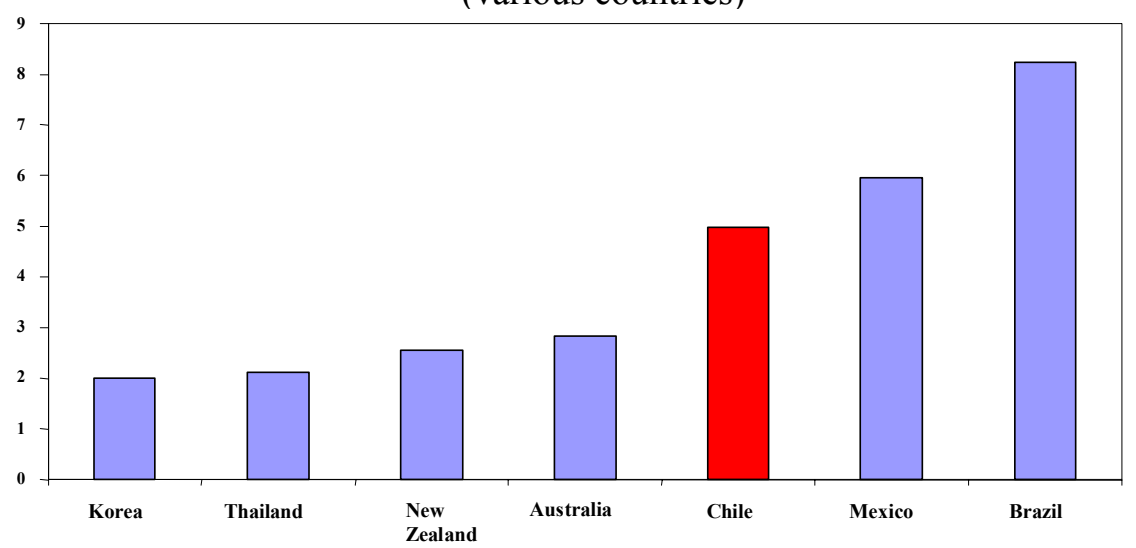

Commercial Banks’ Net Interest Revenue/Other Operating Income, 2002 (various countries)

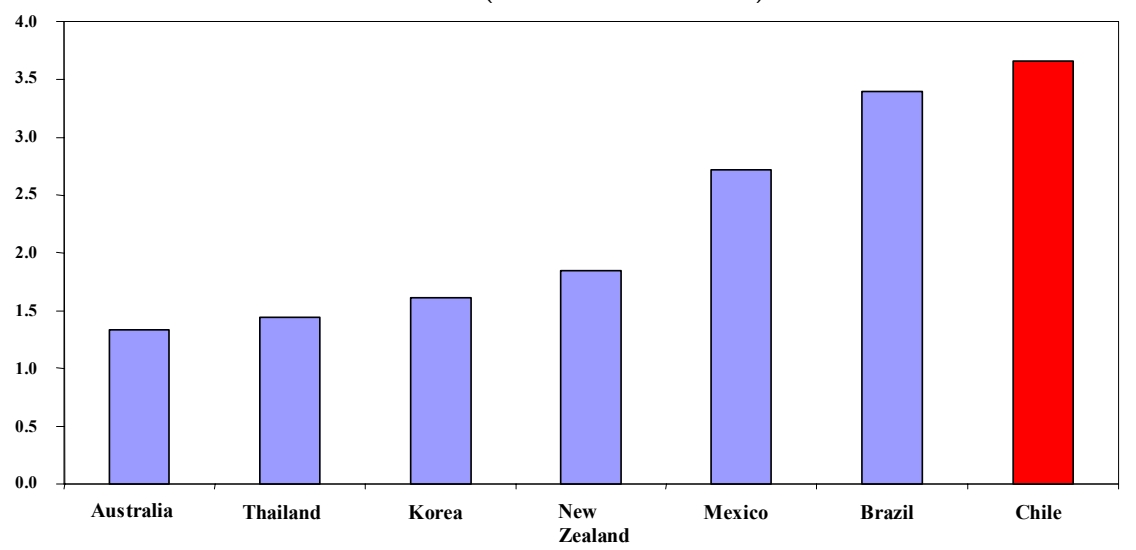

Commercial Banks' Total Operating Cost as a Percent of Total Assets, 2002 (various countries)

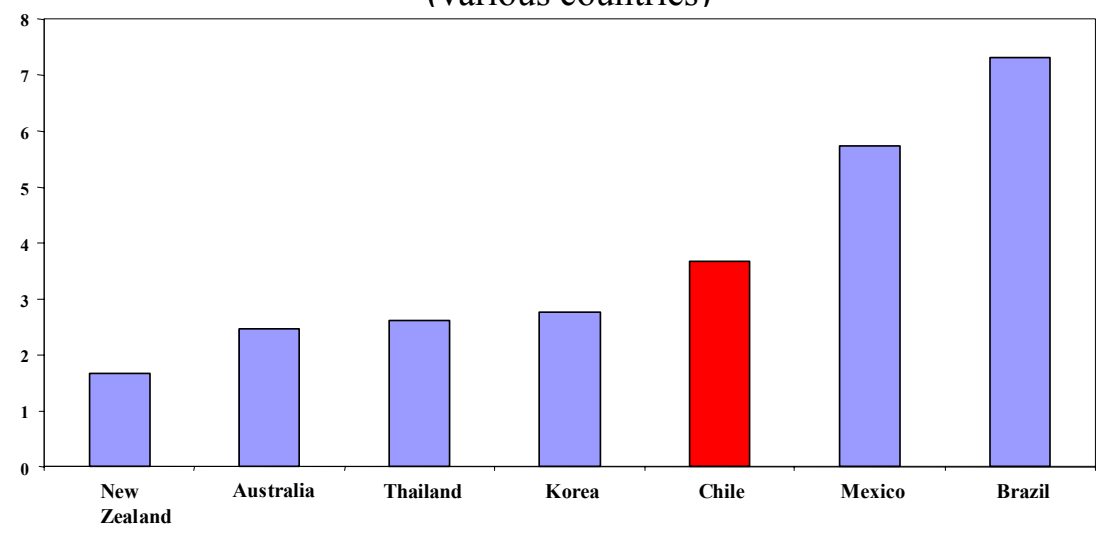

Source: Bankscope. 
22. Competition in the banking industry, while increasing, is yet limited. Competition and innovation have increased during the last few years as a result of the new entrants, increased participation of foreign banks, and the development of the local capital market. Competition is intense for the financing of the very large corporations, which generally have access also to foreign credit and to the local capital markets. It has also become quite intense in consumer credit, partly reflecting the competition from department stores (recently intensified through the direct entry of three stores into the banking business). Yet, competition remains more limited in the middle segment where SMEs have difficulties accessing alternative funding sources and benefiting from direct funding by institutional investors (see below). The dominating presence in the wholesale deposit market of large, risk averse, institutional investors may impress a somewhat conservative bias on banks and stifle competition from non-bank intermediaries, as only the reputable and well-rated intermediaries (mainly the banking groups) benefit from AFP funding. In effect, banks face almost no competition in the credit markets from nondeposit taking finance institutions and, at least until recently, very limited competition from investment and mutual funds. ${ }^{13}$ The scope for competition is limited in some other areas by barriers to entry, notably in retail payment services.

23. Strong financial oversight underpins a robust banking system. Regulation is shared between the BCCh and the SBIF, but supervision is entrusted solely to the latter. The supervisory regime is robust and well established. It enjoys a well deserved reputation for good technical skills and integrity. Efforts have been under way for some time to move away from a strict compliance-driven supervisory style towards one which allows banks more room to manage their risks and compete, while placing increasing responsibility on bank directors and management.

24. However, bank oversight needs to adapt in some areas. The transition to riskbased supervision increases the need for strong analytical and information processing capabilities. Provided it is matched with adequate accountability, this calls for strengthening and clarifying the independence of the SBIF (see below). It also requires adapting the regulatory framework to address some weaknesses identified in the BCP assessment (Annex I). In particular, risk-specific regulations need to be replaced by a broader capital charge for market risk and consolidated supervision expanded beyond banks and their subsidiaries. The scope of fit and proper tests should be extended to banks' directors and senior management. There is also room to further strengthen banks' credit risk management practices and disclosure of risk exposures, particularly as regards derivatives and securitization.

\section{While the Chilean safety net and bank resolution scheme is original and} attractive, it is untested and has some limitations. The scheme, which is based on a

\footnotetext{
${ }^{13}$ The fastest growing segments of the nonbank credit sector (leasing and factoring) are owned by (and increasingly integrated into) banking groups. Similarly, the largest mutual funds are owned by banking groups.
} 
"narrow banking" concept, ${ }^{14}$ remains untested, partly reflecting good supervision supported by an effective system of early warning and prompt remedial action. Should the need to activate the system arise nonetheless, the dominance of large institutional depositors should help expedite the resolution process with only limited losses for all involved parties.

However, obtaining the backing of a majority of creditors (which is needed for resolving the bank) could be lengthy and bothersome if the largest creditors have already left the bank in anticipation of difficulties. When the bank is too big to fail or the system is perceived to be vulnerable to contagion, this could have adverse systemic implications. Under the current regime, a rapid transfer of assets and liabilities of the distressed bank to a sound financial institution is not permitted since it entails a de facto differential treatment of creditors. Nor is it possible for the State to transitorily assume the bank's ownership or for the SBIF to grant a temporary license to a bridge bank. Such options and tools could be usefully integrated into the legal framework.

\section{CORPORATE SECTOR}

26. Chilean firms are conservatively managed, but currently have low profitability. The average leverage ratio at end-2003 was low (1.3), resulting in high debt servicing capacity. However, except in mining and services, the return on equity was significantly below the estimated cost of capital. Firms' depressed profitability, which in part reflects the post-1998 economic slowdown, may have discouraged them from issuing equity in recent years.

\section{SME's access to} finance could be expanded. While banks have recently increased their lending to SMEs through leasing and factoring, there is room to further improve SME's access to finance. Even relatively large firms have limited access to the local bond market, in part because of the large minimum issue size requi red to attract $\mathrm{AFP}$ investment and cover issue fees. The latter are high
Chile: Issuance Cost Breakdown of Selected Instruments (End 2002, Issue of US\$100 million)

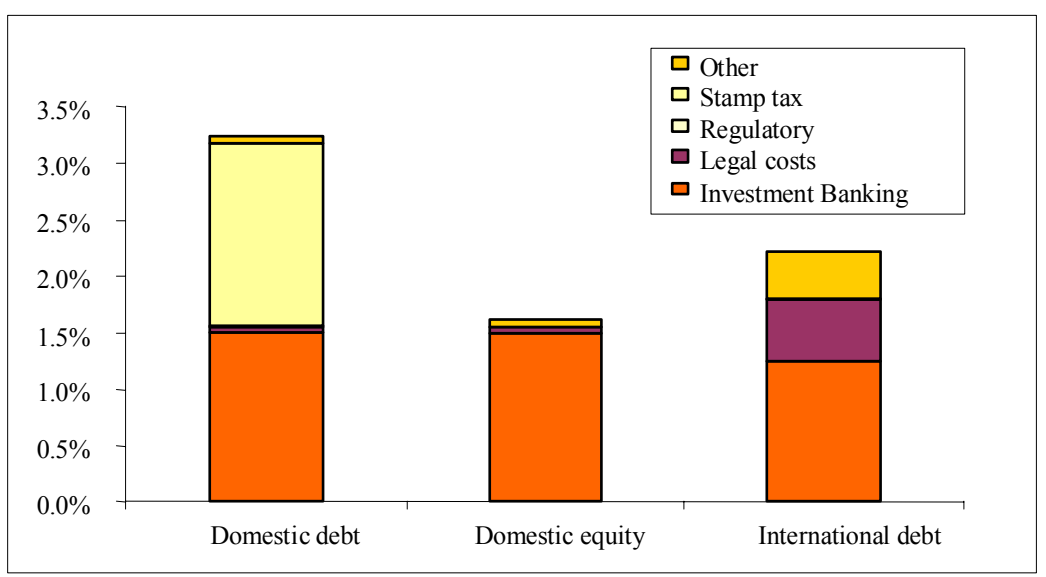

Source: SVS and staff estimates.

\footnotetext{
${ }^{14}$ Sight deposits (and term deposits of less than 30 days or whose term to maturity is less than 10 days) are fully guaranteed by the $\mathrm{BCCh}$ which protects itself from potential losses by requiring that banks hold central bank securities against sight deposits in excess of 2.5 times their capital. If a bank fails, its non-sight liabilities are frozen while sight deposits remain fully accessible.
} 
because of the stamp tax. While Chile's lending environment is already relatively strong, ${ }^{15}$ SME's access to bank finance will be aided by unifying the legislation on movable collateral and creating a single registry for pledges. In addition, the quality of SME financial statements needs to be improved and the ceiling on lending rates (tasa máxima convencional) made more flexible. ${ }^{16}$ A revenue neutral tax reform that eliminates the stamp tax (or exempts smaller customers) should also be considered, as this tax penalizes all forms of Issuance Costs (US\$ 100 million issue) by Instrument, 2003 (various countries)

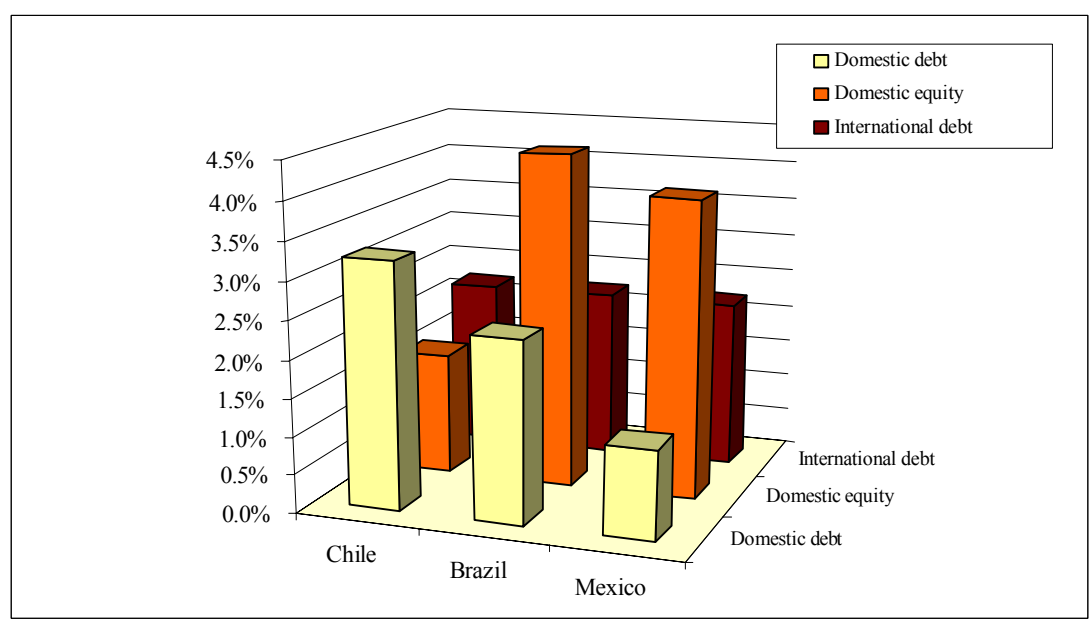

Sources: World Bank and staff estimates. borrowing, especially by the smaller firms. ${ }^{17}$ Firms' access to equity will also be enhanced through a further strengthening of the framework for corporate governance. ${ }^{18}$ Steps include upgrading the accounting and auditing system (see below), clarifying definitions and improving corporate disclosure of related party transactions, and establishing clearer standards for appointing directors.

\section{INSURANCE SECTOR}

28. The insurance sector is large, reflecting its important role in providing annuities. It comprises 57 companies (domestic and international) and its assets have grown steadily to 19 percent of GDP in 2002, up from 7.5 percent in 1992. The industry is dominated by life insurance, which grew in connection with the pension system (it accounts for 62 percent of total premiums, compared to a regional average of 38 percent). Annuities are the dominant choice of retirees due to their high value, which in turn is partly attributable to the availability of inflation-indexed bonds.

\footnotetext{
${ }^{15}$ Chile ranks high (72th percentile) on "effective creditor rights," close to Sweden (75th percentile) and far above Brazil (25th percentile) according to Chong, Galindo, and Micco (IDB, 2004).

${ }^{16}$ A bill that makes the ceiling more product-specific has recently been submitted to Congress.

${ }^{17}$ In addition to raising the cost of borrowing (particularly for the smaller enterprises), there is anecdotal evidence that the stamp tax promotes ever-greening in bank lending.

${ }^{18}$ A 2003 assessment by the World Bank found Chile to score well on the OECD Principles for Corporate Governance. CMII is expected to further strengthen corporate governance.
} 
29. The insurance sector is faced with some under-provisioning of risks, heightened competition and weaknesses in the resolution framework. Provisions will need to be increased to reflect updated mortality tables, make allowance for future improvements in life expectancy, and fully incorporate credit and prepayment risks. ${ }^{19}$ A major part of the sector could fall below the minimum capital requirement once the necessary provisioning is made. This underprovisioning could expose the government to significant losses (about one percent of GDP), given its annuity performance guarantee. At the same time, competition among insurance companies is expected to increase as a result of recent changes in the legal framework for annuities that will allow banks to distribute insurance products and tighten conditions for early retirement (thereby creating a temporary dip in annuity sales). Further complications arise from the low average returns on equity (partly resulting from already very aggressive pricing) and the large number of players, which will require consolidation. Moreover, as illustrated by the 2003 failure of the Inverlink group, ${ }^{20}$ key tools need to be introduced to facilitate an orderly transfer of obligations and dealing with asset deficiencies.

\section{The road map requires a well-designed transition, focused on risk-based} management and supervision. The road map needs to be carefully chartered to limit risks of difficulties surfacing in the years ahead. The increase in provisions and changes to the regulatory requirements must be suitably phased in. Both off site analysis (including a monitoring of market values and pricing, the development of early warning systems, and risk focused capital assessments) and on-site reviews (to gain a better understanding of companies' management and strategies looking ahead) will need strengthening. Care will need to be taken to ensure that the weak financial situation of insurance companies that belong to financial conglomerates does not spill over to other members of the group, particularly banks.

\section{Pension Funds}

31. AFPs are by far the dominant institutional investors in the country. They hold 40 percent of government bonds, 50 percent of mortgage bonds, 38 percent of corporate bonds, and 35 percent of time deposits. ${ }^{21}$ Their number dropped to 6 at end-2003 (from 21 in 1994) following a marketing war in the 1990s. They have enjoyed persistently high profits

\footnotetext{
${ }^{19}$ The current rule-based style of supervision has led insurance companies to devote considerable energy to "managing rules," rather than "managing risks." Exposure to prepayment and credit risks could be more effectively managed in a risk-focused environment.

${ }^{20}$ Inverlink (a financial conglomerate) failed following the revelation that it had benefited from leaks of sensitive Central Bank information. Faced with a run on its mutual funds, the group sold paper-based certificates of deposit that it illegally held, leading to a run on the mutual fund industry (which lost over around 27 percent of its assets in three days). This event raised serious questions about cross-sector contagion, inadequacies in market infrastructure, insufficient internal controls, and ineffective surveillance (see below). Some of these issues are partially addressed in CMII (Box 1).

${ }^{21}$ The fast growth of AFP assets in part reflects high historical real rates of return (7 percent per annum since 1981, well above the 2 percent average real wage growth).
} 
(returns on equity averaged 30 percent in recent years), despite low levels of risk. While costs have declined, more in line with OECD pension funds, there is scope for further reductions. A voluntary pension system (opened to all financial institutions) was introduced in 2002, but it is still small.

Portfolio Composition of Pension Funds (\%): Chile and Selected Countries

\begin{tabular}{l|ccccc|c|cc}
\hline Country & $\begin{array}{c}\text { Cash and } \\
\text { Deposits }\end{array}$ & $\begin{array}{c}\text { Bills and } \\
\text { Bonds }\end{array}$ & Loans & Shares & Other & Total & Foreign & $\begin{array}{c}\text { Assets/ } \\
\text { GDP }\end{array}$ \\
\hline Chile (2003) & 15.0 & 45.6 & 0.0 & 37.8 & 1.6 & 100.0 & 23.8 & 59.9 \\
\hline Australia (2002) & 7.7 & 19.8 & 3.9 & 59.8 & 8.9 & 100.0 & 19.1 & 67.4 \\
Canada (2001) & 0.4 & 40.7 & 2.9 & 49.6 & 6.4 & 100.0 & 21.4 & 48.2 \\
Denmark (2001) & 1.3 & 49.2 & 1.6 & 45.6 & 2.3 & 100.0 & 25.0 & 23.8 \\
Ireland (2001) & 2.8 & 21.4 & 0.0 & 65.6 & 10.2 & 100.0 & 67.8 & 44.7 \\
Netherlands (2001) & 1.5 & 34.7 & 8.8 & 49.5 & 5.4 & 100.0 & 65.0 & 105.1 \\
Spain (2001) & 16.0 & 50.9 & 0.6 & 21.0 & 11.5 & 100.0 & 34.3 & 6.8 \\
Switzerland (2000) & 7.3 & 31.2 & 12.0 & 33.9 & 15.6 & 100.0 & 25.0 & 121.1 \\
United Kingdom (2001) & 3.2 & 13.9 & 0.0 & 60.9 & 22.1 & 100.0 & 22.9 & 69.2 \\
United States (1998) & 3.6 & 20.9 & 1.6 & 61.6 & 12.2 & 100.0 & 11.0 & 72.0 \\
\hline
\end{tabular}

Sources: SAFP, OECD, APRA, Irish Pension Fund Association, Danish Supervisor, Davis (1995 and 2001).

\section{Pension funds' portfolio composition reflects structural constraints and an} overly complex and restrictive investment regime. Despite the significant increase in their share of foreign assets (to almost 30 percent) and the introduction of multiple funds among which workers can choose (to increase risk diversification), pension funds continue to have a relatively high level of low-yield, short-term assets, mainly bank certificates of deposits. The share of domestic equity is small, the range of equity holdings is

Chile: Corporate Debt Outstanding by Credit Rating, 2003

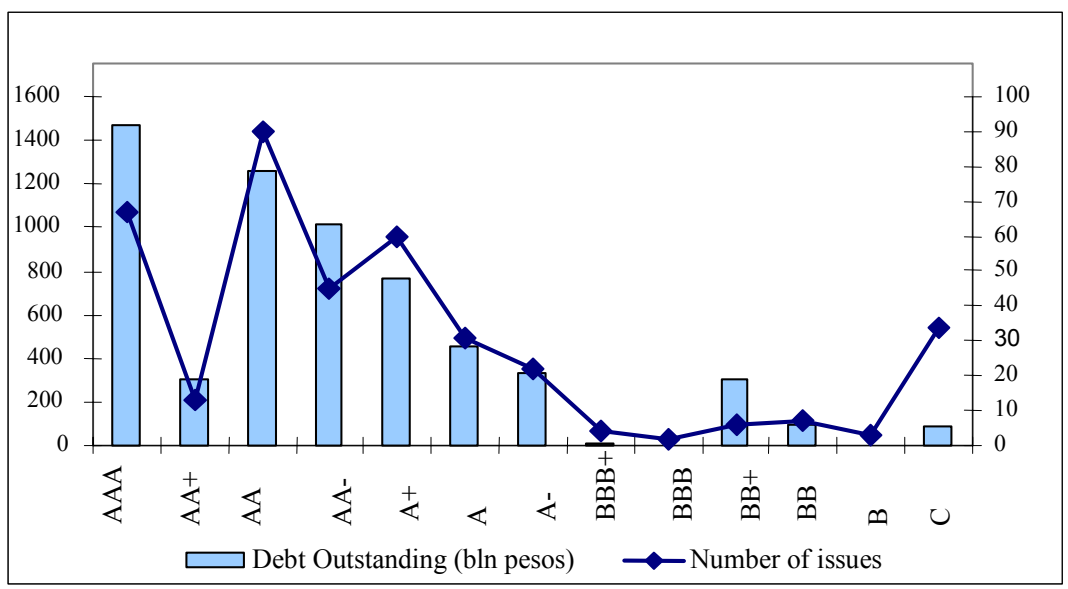

Source: SVS. narrow (90 corporations, out of more than 200 listed companies), and corporate bond holdings are heavily concentrated in companies rated $\mathrm{A}$ and above. This is mainly the result of the fast growth of AFPs outstripping the availability of investable assets in a relatively small and undiversified economy, a problem that was exacerbated in recent years by the decline in aggregate investment. Pension funds are so large relative to the size and liquidity of domestic securities markets that fund managers face difficulties in selecting assets in which to invest without creating price bubbles or becoming locked in their investments. They thus "pick" a few, liquid securities issued by the most reputable issuers, fully use their 
allowance to invest abroad, and invest their residual funds in bank CDs. The resulting segmentation in access to bond finance is also a reflection of an investment regime that is excessively complex and over-determined, with a multiplicity of limits on instruments, classes of instruments and issuers, and sub-limits on instruments and combinations of instruments.

33. There is ample room to simplify AFPs' investment regime without undermining their primary fiduciary function. Policies may be considered to enhance AFPs' impact on financial development only to the extent that their main objective is safeguarded. A conservative portfolio allocation is particularly justified in Chile given that the second (mandatory, privately-administered, fully-funded) pillar of the system constitutes the core of the national social security scheme. A major liberalization of the investment regime would therefore not be advisable. In particular, the main ceilings on investment in major instruments (to ensure overall safety) and the basic limits by issuer (to avoid excessive concentration and minimize connected lending) should be maintained. However, most sub-limits on instruments, all sub-limits on combinations of fixed-income and variable-income instruments, and all the "specific reducing factors" on issuers (linked to concentration, diversification, liquidity, and other factors) could be removed. The approval process for eligible investments could be streamlined, permitting investment in all listed equities except for a reasonable negative list and allowing marginal holdings of below-grade corporate bonds. This rationalization should be accompanied by a shift from compliance-based to riskbased supervision. ${ }^{22}$

34. Regulatory improvements are also recommended regarding foreign investments. The recent increase of the ceiling on investments abroad should provide long-term risk diversification benefits considering the small size and openness of the Chilean economy. While further increases in the ceiling may be advisable in the future, the already large stock of foreign assets needs to be better managed. This requires, inter alia, allowing the use of more instruments to hedge risk (such as currency swaps), correcting definitional and misclassification problems in mutual fund investments, increasing the ceilings on individual foreign shares and mutual funds, and permitting that fees on foreign mutual funds be netted from the gross returns (to level the playing field with investments in mutual funds at home).

\section{The authorities should also deepen their efforts to gradually enhance} competition in the pension sector. Greater competition in asset management should not only contribute to a further lowering of fees but also to a broader diversification of investable funds. Further outsourcing of administrative services could be encouraged while regulating service providers more effectively. The authorities are also encouraged to implement their plans for "decompressing" the mandatory pension system (members that achieve a threshold balance in their mandatory pension can be diverted to the voluntary pension system) and enhancing in various ways its attractiveness.

\footnotetext{
${ }^{22}$ This includes training of staff on risk management techniques and the introduction of a compliance officer inside each AFP reporting directly to the AFP Board.
} 
36. Should this gradual approach fall short of expectations, a more radical reform could be introduced at a later stage. This would unbundle pension-related services that are subject to economies of scale (contributions collection, accounts management, payouts to retirees, etc.) from those services where price competition can thrive (asset management). Among other alternatives, a blind quotation system (workers know which asset manager they choose but asset managers do not know the identity of the workers whose pension assets they manage) could be introduced. ${ }^{23}$

\section{Policies should also be considered to reduce the market risks faced by workers at} the moment of retirement. The current system, which separates the administration of retirement savings between AFPs and life insurance companies (each operating under different market incentives) is not necessarily consistent with maximizing workers' consumption for a given level of risk. To protect retiring workers from interest rate risk when switching from the pension fund to annuities, a long-duration fund could be introduced and workers allowed to purchase fixed annuities gradually in the years before retirement.

\section{SECURITIES MARKETS}

38. While Chilean Average Free Float Ratios for Emerging Equity Markets, 2003 securities markets are large, their liquidity remains limited. Secondary market liquidity lags that in comparable emerging market countries, particularly in corporate paper, mortgages, and equity markets. The illiquidity of the equity market reflects both concentration of

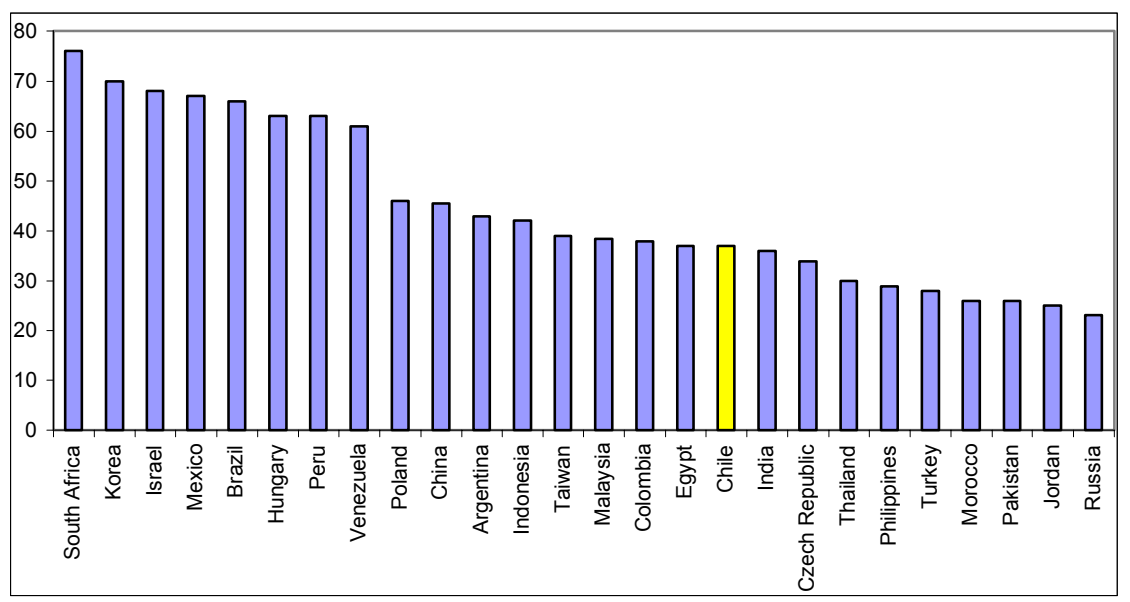

Source: World Bank. supply (the concentrated firm ownership results in very low "float ratios;") and concentration of demand at six AFPs which mostly "buy and hold." ${ }^{24}$ Enhancing liquidity is essential to securities markets development. Due to incentive problems among the various capital market participants to act collectively, this will require strong leadership and a major coordination effort.

\footnotetext{
${ }^{23}$ The experience of Sweden and its recent adaptation to Latvia is illustrative. Risks of excessive entries could be mitigated through proper licensing criteria.

${ }^{24}$ The significant migration of securities issues and trading abroad has also reduced liquidity in the domestic capital market.
} 
39. Legal voids that affect the clearing and settlement of securities need to be filled. ${ }^{25}$ Deficiencies as regards security transactions and registering became more evident in the wake of the Inverlink scandal. The forthcoming introduction by the BCCh of a real-time grosssettlement payments system and the nearly complete move towards dematerialization of securities will go a long way towards enhancing the transparency and safety of security transactions. However, the legal foundations for securities clearing and settlement would be strengthened by embedding more clearly in the law the concepts of finality, netting, and novation (the substitution of an old obligation or obligor with a new obligation or obligor). The concept of netting should be introduced as part of a broader reform of the bankruptcy code. Embedding novation and netting in the law would facilitate the introduction at a later stage of multilateral netting arrangements and a central clearing counterparty.

40. Reforms

are needed to facilitate market trading and enhance market liquidity. Such efforts should affect securities traded in both the exchange and over the counter (OTC).$^{26} \mathrm{In}$ particular, securities valuation, already undermined by secondary market illiquidity, is further hampered by inadequate price
Chile: Daily Trading Volume, 2003

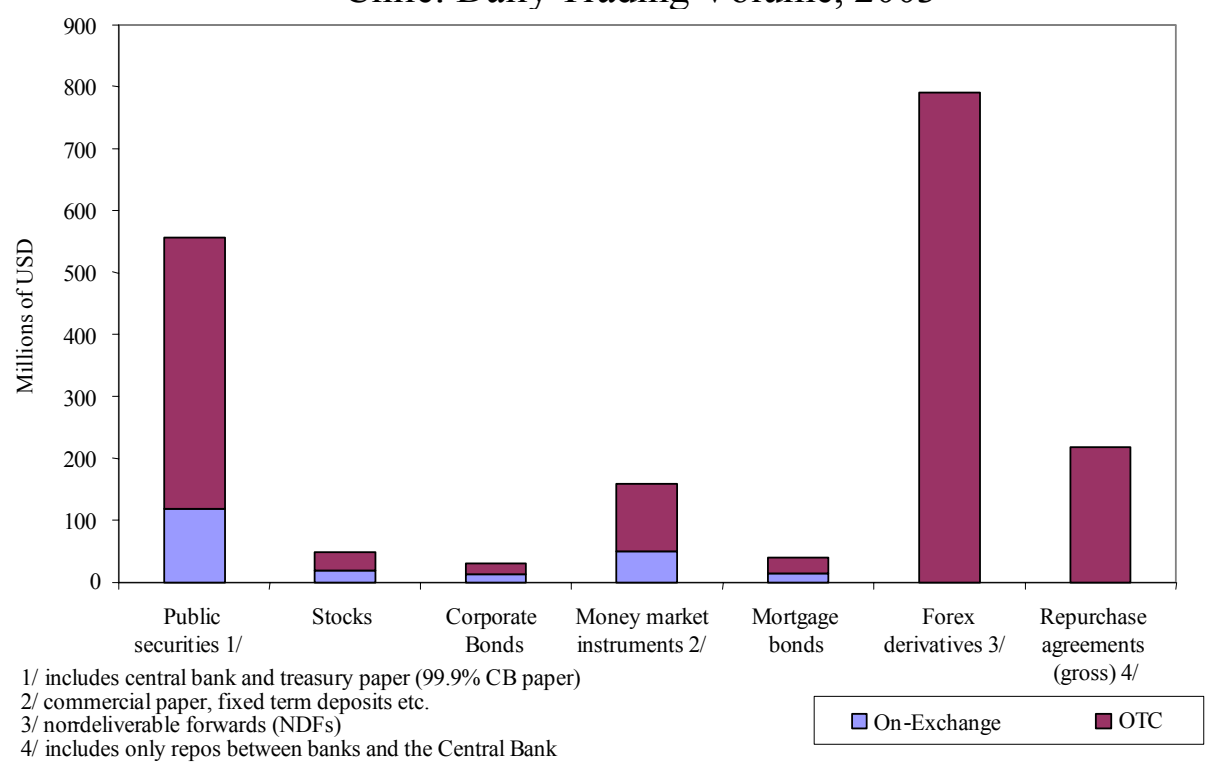

4/ includes only repos between banks and the Central Bank

Sources: DCV and Central Bank.

information on OTC trades and lack of uniformity in valuation methodologies. The authorities should consider introducing a standard contract for repos (and, possibly, an omnibus master agreement for both repo and derivatives contracts). More generally, a comprehensive review of shortfalls in contract standardization, including in the highly fragmented mortgage market, would be desirable. At the same time, a market for securities

\footnotetext{
${ }^{25}$ Informal assessments of observance of the CPSS Core Principles for Systemically Important Payment Systems and the CPSS-IOSCO Recommendations for Securities Clearance and Settlement were conducted as part of the FSAP.

${ }^{26}$ OTC trading dwarfs the exchange-based trading.
} 
lending and borrowing needs to be promoted and a suitable formalization of a market making system considered. ${ }^{27}$

\section{The financial reporting regime for companies listed on the stock exchange}

should be strengthened. ${ }^{28}$ Chilean accounting principles differ significantly from

International Financial Reporting Standards (IFRS). They fail to require disclosure on certain critical areas, and are not as rigorous as IFRS in disclosing the fair value of financial instruments, especially derivatives. Chile should adopt IFRS after an adequate period of transition. As regards external auditing, the current lack of licensing and quality control mechanisms in the audit profession weaken its role, potentially compromising the overall strength of the reporting system. The current efforts toward creating a licensing system are welcome.

\section{While securities market regulation is basically sound, important weaknesses} need to be addressed (Annex I). The SVS would benefit from a significant increase in budgetary and staff resources. There is also a need to: (i) introduce minimum professional standards for the securities industry; (ii) submit brokerage firms to internal compliance programs and ensure their fiduciary duty rule; and (iii) grant the SVS powers to suspend individuals for misconduct, finalize disciplinary action via negotiated settlement rather than court litigation, and intervene (or appoint a conservator or liquidator for) a failing brokerage firm. The intervention power should be coupled with the creation of an industry-wide guarantee fund to facilitate an orderly settlement of transactions and limit the ripple effects of a failure.

\section{HedgeS}

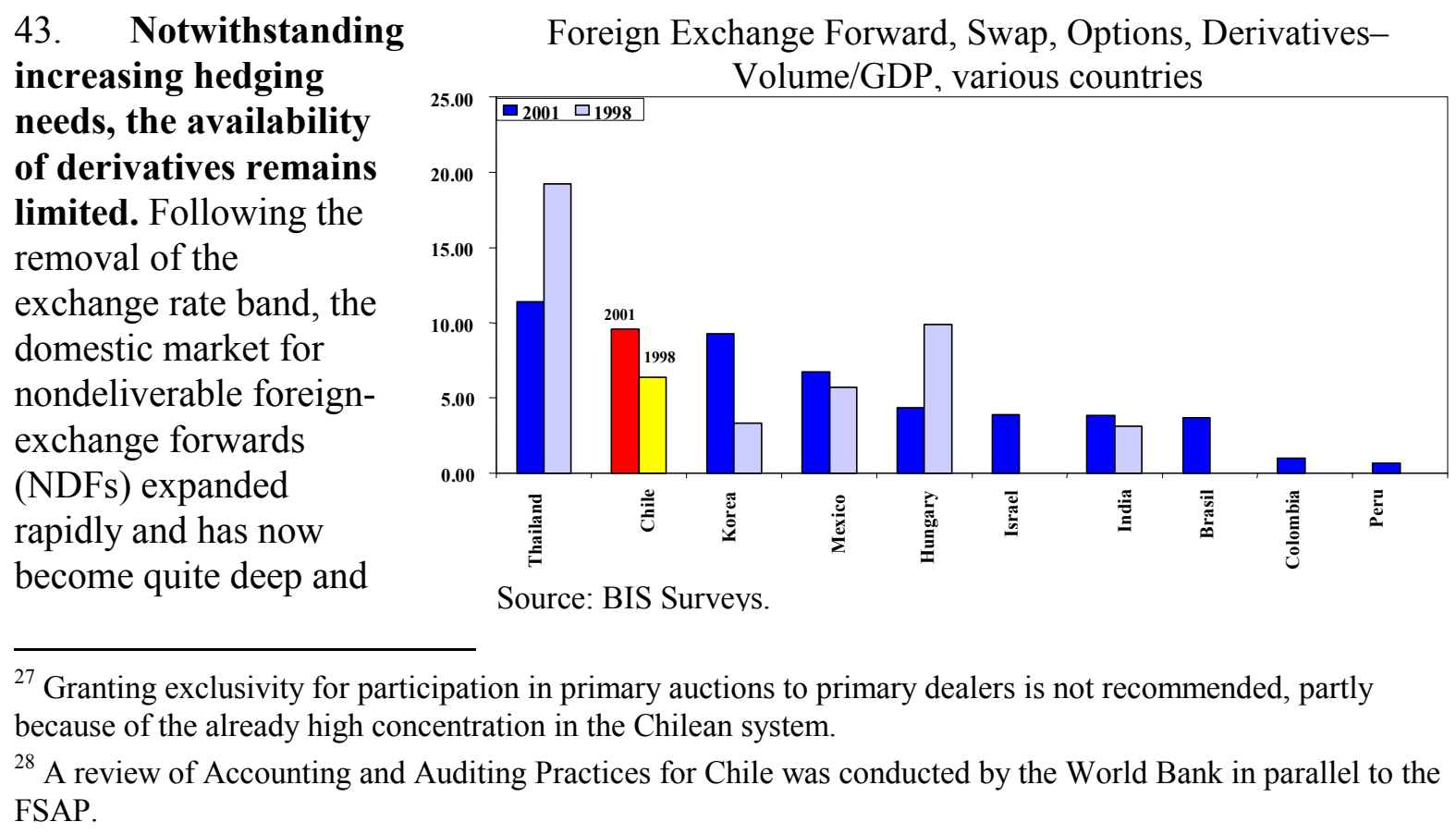


liquid. However, the use of other derivatives remains extremely limited. In particular, there is no active interest rate derivatives market. Yet, as already noted, some sectors, including life insurance, are highly exposed to interest rate risk, reflecting a substantial duration gap and a large exposure to repayment risk. Similarly, the absence of equity derivatives and options of any kind hinders the capacity of financial intermediaries and corporates to manage and allocate risk effectively.

Such gaps will become increasingly binding as the financial system evolves from "managing rules" to

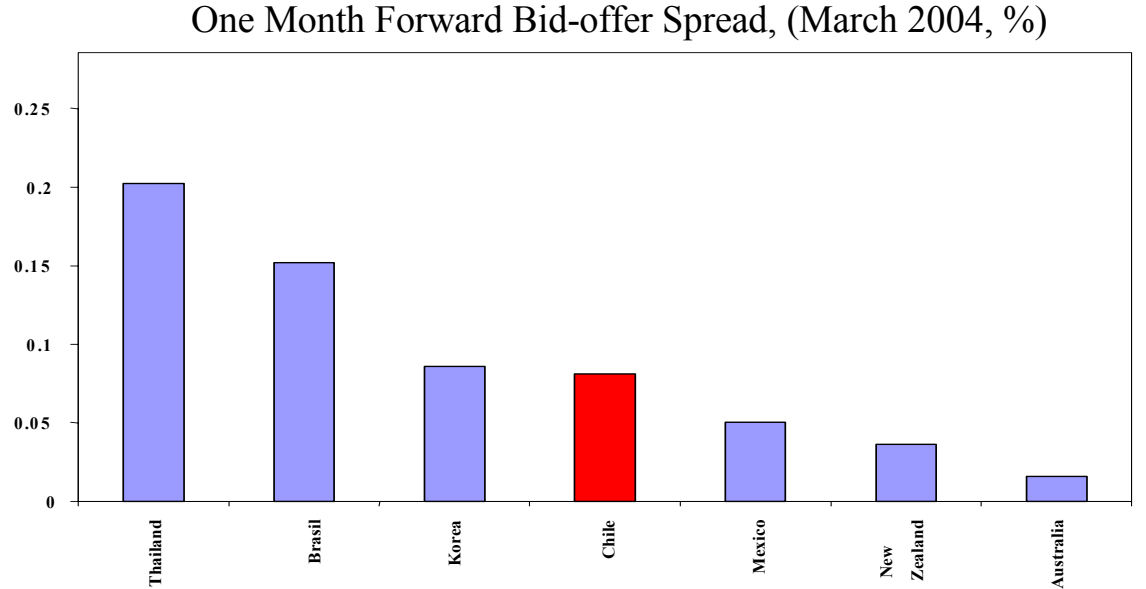
Source: Bloomberg.

"managing risks." Moreover, new derivatives would help increase trading in assets that are now locked in institutional investors' portfolios, thereby contributing to market liquidity.

44. The development of new derivatives products should be fostered by a cautious relaxation of current restrictions and enhancements to market infrastructure. The limited development of derivatives reflects both regulatory barriers on trading, that affect banks, pension funds and insurance companies, and deficiencies in information and market infrastructure. While a relaxation of regulatory restrictions is advisable, some caution is needed given the limited liquidity of underlying markets (particularly equity), which hinders the use of derivatives and increases their risks. The restriction on banks to write options could be removed after a capital charge for market risk has been introduced and supervisors are satisfied that banks have adequate capacity to manage the associated risks. This may also require capacity building at the SBIF. The removal of restrictions on derivatives trading for AFPs and insurance companies would be a logical second step, based on similar requirements. As regards market infrastructure, there is a need to: (i) follow intraday market indicators to measure liquidity and ascertain disorderly market conditions; (ii) increase the data available to the public to promote competition and avoid manipulation; (iii) enable netting and securities lending; (iv) define a proper tax, accounting, and valuation treatment of derivatives; and (v) promote knowledge building, standardization of contracts, and an industry code of conduct.

\section{Cross-Sectoral Issues in Financial OVERSIGHT}

45. Supervisory oversight is currently based on a segmented ("silo") approach, strong firewalls, and mostly informal coordination arrangements. Supervisory responsibility is segmented by type of financial entity and distributed among three superindendencies (banks, securities and insurance, and pensions). The BCCh retains 
significant regulatory powers and pre-eminence in systemic stability matters while the MoF provides leadership in financial sector development policy. This silo approach is supported by strong firewalls that include limits on permissible activities, cross-ownership, and connected lending and investments, as well as prohibitions on sharing infrastructures and customer bases. While inter-agency coordination has been strengthened in recent years, the two main coordinating bodies, the Superintendents Committee and the Capital Markets Committee, have no legal basis and there is no comprehensive framework that describes the roles and responsibilities of each participant. $^{29}$

\section{The segmented approach will become increasingly limiting as financial services} become more integrated and complex. The problems that could have arisen from the coexistence of institution-oriented supervision and the dominance of financial conglomerates have hitherto been kept at bay by firewalls, comfortable profitability, and the strong presence of prestigious foreign banks supervised by their home-country regulators. However, rapid changes in financial services are increasingly exposing the limitations of this approach. As evidenced by the thriving yet opaque OTC market, there are gaps in market transparency and surveillance that involve different types of financial entities subjected to different regulations and that fall outside the purview of any of the individual regulatory agencies. In addition, the uneven regulatory treatment of similar products promotes regulatory arbitrage. ${ }^{30}$ Moreover, statutory obstacles to the consolidated supervision of financial conglomerates beyond the bank holding company could impede early recognition of group-wide risks, especially in cases where the conglomerate includes nonfinancial firms. The importance of these linkages will rise as financial groups are increasingly driven by competition to exploit synergies and scale economies.

\section{Improved inter-agency coordination and enhanced analytical and informational} capacity will be needed. While cooperation between regulators has improved, it remains limited in view of the range of issues that require coordination. As the Inverlink case showed, the result can be a reduced ability to detect emerging problems, as well as increased potential for arbitrage and inefficiencies. Despite important inroads by the BCCh in financial system stability analysis, issues at the interface between the different components of the financial system and between macro-financial developments and micro-market underpinnings will require more attention. This problem is often exacerbated by shortcomings in the overall analytical capacity of the supervisory agencies and weaknesses in data collection and information systems. ${ }^{31}$

48. Reforms should focus, in the short term, on enhancing cooperation among regulators and filling the gaps in information, analysis, and market surveillance. Much can be achieved in the short-term, without legal reform, within the current organizational arrangements. The functions of

\footnotetext{
${ }^{29}$ While CMII would give stronger legal grounding to information sharing, cooperation would remain rather informal and limited in scope.

${ }^{30}$ For example, insurance companies can originate consumer loans and mortgages and launch mutual fund and credit card subsidiaries, but are subject to different regulations than banks. Voluntary pension funds will be subject to the same (SAFP) regulations as mandatory pension funds when administered by AFPs but by different (SVS) regulations when administered by other financial entities.

${ }^{31}$ While information systems are often adequate in meeting the needs of silo-based supervision, they generally fall short in supporting more analytic, broader, cross-sectoral, systemic analysis.
} 
the two coordinating bodies can be suitably redefined, and their operating principles and protocols formalized via a well-designed MOU. Consideration should be given to the creation of a small but competent permanent technical secretariat focusing on the analysis of cross-cutting issues and the coordination of efforts to rationalize (and facilitate access to) information. Efforts should also be made to boost the overall analytical capacity of the agencies and broaden the scope of analysis, for example through a program of regular staff exchanges.

Chile: Re-defining the Roles of Coordinating Bodies

\begin{tabular}{|l|l|}
\hline \multicolumn{1}{|c|}{ Capital Markets Committee } & \multicolumn{1}{c|}{ Committee of Superintendents } \\
\hline Financial policy (legislative changes) & $\begin{array}{l}\text { Policy implementation and regulation } \\
\text { Issues pertaining to better exercise of supervisory functions } \\
\text { Sefinition and monitoring of risk profiles and activities of financial } \\
\text { conglomerates } \\
\text { Monitoring connections across financial system } / \text { market developments } \\
\text { Systemic crisis management policy }\end{array}$ \\
\hline
\end{tabular}

49. For the medium term, legal reforms will be needed to support fully consolidated supervision. The authorities should consider legislative reform to define and embed the concepts of financial conglomerate, financial holding company, and lead regulator in the law and, hence, appropriately underpin the full application of consolidated supervision. This should be established simultaneously with some relaxation of existing firewalls, while ring fencing the financial conglomerate from the rest of the group. In addition, the authorities are encouraged to improve coordination protocols to deal with the possible failure of a complex financial conglomerate.

50. The shift from "managing rules" to "managing risks" puts a premium on further enhancing the autonomy and legal protection of supervisors. The authorities should consider reforms to enshrine in the law the political and budgetary autonomy of the regulatory agencies, and enhance the legal protection of supervisors. To minimize the scope for abuses of power and inefficiencies, increased autonomy must be matched with increased transparency and accountability.

\section{Anti-Money LAUndering}

\section{Further to the $\mathbf{2 0 0 3}$ GAFISUD assessment, there remains scope for tightening} the AML/CFT framework. The recent passage of a law endorsing the authority of a Financial Intelligence Unit (FIU) and extending the definition of offences and the institutions subject to reporting constituted an essential first step towards compliance with AML/CFT standards. However, subsequent rulings of the Constitutional Court eliminated the FIU's sanctioning powers, limited its discretion in requesting data on suspicious transaction records, and denied its access to information protected by bank secrecy or on other public databases. This undermines investigations on (and the disclosure of) potential offences, precluding effective international cooperation through the FIU, including in freezing assets. The monitoring of compliance by securities firms, insurance companies, and foreign exchange retail operators also needs improvement. 


\section{ObSERVANCE OF FinanCial SECTOR STANDARDS AND CODES: SuMMARY ASSESSMENTS}

This annex contains detailed assessments of Chile's observance of three international standards and codes applicable to the financial sector. The assessments have helped to identify the extent to which the regulatory and supervisory framework in Chile is adequate to address the potential risks in the financial system, as well as the strength of the underlying regulatory governance practices and market foundations, and the functioning of market infrastructure. The assessments have provided the basis for making recommendations for further strengthening of the institutional, legislative and regulatory aspects of the Chilean financial stability framework.

The Financial System Stability Assessment (FSSA) is based on the work of the joint IMF-World Bank FSAP missions to Chile in December 2003 and March 2004 co-led by Messrs. Ize ( IMF) and de la Torre (WB). The FSAP assessors are as follows: Messrs. Brian Quinn (formerly Bank of England) and Juan Ortiz (WB/Bank of Spain) for the Basel Core Principles for Effective Banking Supervision; Jonathan Katz (U.S. SEC) for the IOSCO Objectives and Principles of Securities Regulation; and; Ms. Marie Thérèse Camilleri (IMF) for the IMF Code of Good Practices on Transparency in Monetary Policies.

The assessments were preceded by self-assessments undertaken by Chilean authorities, which were evaluated during the FSAP, by focusing on actual practices and verified through discussion with Chilean authorities, market participants, and industry associations.

Chile's observance of international financial sector standards and codes is very strong, even though in each area, certain aspects were identified where further improvements would be desirable. The Chilean authorities are well aware of the areas that need further reforms and are in the process of addressing them. 


\section{Basel Core Principles for Effective Banking SuPERVision}

\section{A. General}

52. The assessment is based on several sources: (i) the legal and regulatory framework, contained mainly in the Banking Law (Ley General Bancaria, LGB); in regulations issued by the BCCh and the SBIF, which are compiled in two compendia (Compendio de Normas Financieras and Recopilación Actualizada de Normas); and (ii) examination of key documents and discussions with SBIF senior staff; (iii) discussions with relevant government agencies, as well as bankers, auditors, and rating agencies; and (iv) the assessment report on Chile's observance of the Core Principles, prepared by external consultants in February, 2000. The assessors benefited from the full cooperation of the Chilean authorities and received all information necessary for the assessment.

\section{B. Main Findings}

\section{Introduction}

53. The supervisory regime is well established and enjoys a reputation, both inside and outside the banking community, for good technical skills and for integrity. The lessons of the banking crisis of the early 1980s are well embedded, but there has been a conscious policy of moving away from a hands-on, compliance-driven style towards one that places increasing responsibility for prudent conduct on the boards of directors and senior management of the banks. There has been a correspondingly greater emphasis on corporate governance. This transition has increased the need for the banks to further strengthen their risk management, and the need for the supervisors to develop further the current risk-oriented supervisory approach, where appropriate training and IT capacities are paramount.

54. The Superintendency is already managing some of these developments and appears to be doing it effectively. In particular, the policy of placing greater responsibility on bank boards and management for the prudent conduct of the bank is both consistent with international best practice, and is being reflected in changes in the legal and regulatory framework. The banks are conscious of this change in approach and appear to be equipping themselves to implement it. This shift in emphasis may lead to more active and adventurous behavior by banks and to pressure for the formation of a larger number of broader financial services groups which contain banks. If so, consideration should be given to a strengthened legal framework if these changes are to take place without endangering stability.

55. Chilean accounting norms for banks depart in a number of respects from international standards. These differences include accounting for credit limits and other underwritings, as well as accounting for NPLs and reserves for loan losses. From a prudential viewpoint this does not appear to be a significant issue, as supervisory requirements for provisions for bad and doubtful debts, and for write-offs, appear to be prudent and carefully monitored. However, comparison with the published accounts of banks in other countries employing 
international standards is difficult and raises unnecessary questions about the relative safety and soundness of Chilean banks.

\section{Objectives, Autonomy, Powers, and Resources (BCP 1)}

56. Notwithstanding a strong supervisory culture, some of the institutional arrangements for banking supervision are flawed and should be strengthened. Although the SBIF is legally established by the Banking Act, the Superintendent is appointed by the President of Chile, has no fixed term of appointment, and may be dismissed by him without cause; it is customary for the Superintendent's term of office to coincide with that of the President, a practice which carries the risk of politicizing the office.

57. The SBIF staff do not enjoy the same job-security available to other public servants. They are appointed by the Superintendent and may be dismissed by him personally without reason other than the general grounds of failure to perform their duties. That said, staff numbers at the SBIF appear to be stable and morale is good.

58. The SBIF has little control over its financial resources. These are derived from a levy on commercial banks, divided equally between the budget of the SBIF, which has to be approved by the MoF, and the Ministry itself. In practice, the SBIF appears to have sufficient funds its needs, including adequate numbers of well-trained staff. However, the current system not only puts this at risk by its informal nature, but also obscures the efficiency with which this effective tax on banks is used.

59. The legal protection available to SBIF officials in discharging their duties appears to be limited to protection against physical abuse or defamation arising from the performance of their duties. Supervisory staff are subject to civil legal action for negligence and there is doubt whether they could receive financial support in defending themselves in such actions. The penalties that supervisory staff may therefore incur could encourage a compliance-based style that contradicts with the current efforts to provide incentives to the commercial banks to take greater responsibility for their affairs. It is possible that the exercise of greater discretion by bank supervisors to encourage this change in behavior by banks' management could expose supervisors to an increased probability of legal pursuit. This could, over time, affect the SBIF's efforts to attract and retain quality staff.

60. Greater autonomy for the SBIF and increased legal protection for supervisors should be accompanied by greater accountability. The precise institutions and machinery required to deliver this additional accountability would be for the government to determine, but might include some combination of enhanced internal controls and independent professional external scrutiny. Improved governance for the SBIF should, if properly designed and executed, further enhance the reputation which it already enjoys.

61. Further consideration should also be given to redefining the role and objectives of the SBIF. Currently the SBIF is the sole agency with powers to grant banking licenses, and normally does so after receiving a formal opinion from the BCCh. However, the SBIF can 
withdraw a license only with the prior approval of the BCCh. While the Banking Act is administered by the SBIF, the issuance of many regulations governing prudential requirements on banks is the responsibility of the BCCh. On the other hand, the SBIF has adopted the mission of ensuring public confidence in the banking system, a task that falls in many countries to the central bank or, at least, is shared with it.

62. These arrangements are untidy and, more importantly, weaken the authority of the SBIF. While it is acknowledged that the BCCh has an important stake in maintaining the stability of the banking system, most notably as guarantor of certain bank deposits, it would be greatly preferable to confine the responsibility of the SBIF to the prudential regulation of institutions authorized to conduct banking business; and to give it the powers to carry out this task in all respects: issuing regulations, licensing and supervising banks and applying the necessary sanctions, including withdrawing licenses after consultation with the BCCh.

63. Co-ordination and co-operation among the various supervisory and regulatory agencies is working effectively, but needs to remain abreast of developments in the financial sector. The SBIF meets with other agencies at the Superintendents' Committees, with the $\mathrm{BCCh}$ and the MoF also present in the Capital Markets Committee. These arrangements appear to work well and would probably continue to do so as long as the financial landscape remained unchanged. However, as financial goods and services are increasingly spilling over institutional and regulatory boundaries, as has commonly happened abroad, new arrangements may well be needed, including clear formal arrangements for defining responsibilities, for framing regulations, for information sharing, and for acting in an emergency. This could be done via MOUs and formal terms of reference for the Superintendents' Committee that would close potential gaps in the supervisory net, and avoid ambiguity in the agencies' responsibilities. The appointment of a lead regulator or coordinator for meetings of the Superintendents' Committee, supported by a small secretariat and the definition of its terms of reference, also should be considered.

\section{Licensing and Structure (BCPs 2-5)}

64. Present framework enables the SBIF to assess the ownership structure of banking organizations, including the banks' direct or indirect controlling shareholders, as well as the operations and strategies proposed for the bank. While the law empowers the SBIF to apply a fit and proper test to applicants for a banking license, the criteria are limited to financial solvency and moral integrity, and do not include experience or expertise in banking or financial management appropriate to the activities of the bank. The SBIF carries out checks on the competence and experience of controllers of banks but this is done on an informal, and therefore legally doubtful basis.

\section{Prudential Regulation and Requirements (BCPs 6-15)}

65. Chilean financial institutions must maintain a minimum level of capital with respect to their risk-weighted assets and other commitments in line with the Basel Capital Accord, but are not required to maintain capital against market risks. On January 2004, a new 
regulation for the grading of loans and the determination of the provisions for loan losses entered into effect. The new system is inspired by the Basel II model and employs ten loan grades. The Chilean supervisory authorities have adopted a conscious policy of placing increasing responsibility on management, enhancing thus managerial practices and internal controls. AML/CFT legislation has recently been materially strengthened, supporting the efforts of the SBIF to encourage supervised institutions to implement KYC rules.

\section{Methods of Ongoing Banking Supervision (BCPs 16 - 20)}

66. The supervisory model of the SBIF is comprehensive but its scope needs to be extended to permit the identification of all the risks in a group, whether they lay within the banking group or in an affiliated company. The SBIF can perform on-site examinations on all institutions within a banking group, including their subsidiaries at home and abroad. Off-site supervision is based on the financial information and reports submitted by banks to the SBIF, on the results of on-site inspections, on internal and external auditors' reports, and public information. The scope of consolidated supervision under the current law ends at the level of the bank holding company and therefore fails to capture risks in other parts of a broader group that could endanger the bank. Other companies outside the banking group, which are associated through common directors or a common name, may create risks for the bank which could threaten the interests of depositors if difficulties should arise in these companies. Supervisors should therefore have the powers to obtain any such information through the authorized bank. Controllers of the bank holding company are requested to provide information on their financial position and on their other interests outside the bank; but they are not obliged to do so, even if requested by the SBIF.

\section{Information Requirements (BCP 21)}

67. The audited financial statements of banks do not follow closely internationally accepted practices and standards, hindering comparison with other countries. However, these differences do not raise any particular prudential concerns.

\section{Formal Powers of Supervisors (BCP 22)}

68. The legal framework grants the SBIF sufficient and comprehensive powers for prompt corrective action, through either rehabilitation procedures or closure and liquidation. In addition, supervisors have at their disposal a broad range of powers that are available to impose graduated remedial actions.

\section{Cross-Border Banking (BCPs 23 - 25)}

69. The SBIF has the authority to perform global consolidated supervision and to share information with foreign supervisors. The SBIF has signed MOUs with relevant foreign supervisory authorities. 


\title{
C. Recommended Action Plan and Authorities' Response to the Assessment
}

\author{
Recommended Action Plan to Improve Compliance of the Basel Core Principles
}

\begin{tabular}{|c|c|}
\hline Subject & Recommended Action \\
\hline $\begin{array}{l}\text { Objectives, Autonomy, Powers, and Resources } \\
\text { (BCP 1) }\end{array}$ & $\begin{array}{l}\text { Strengthen the institutional arrangements of banking } \\
\text { (and financial sector) supervision. At a minimum, the } \\
\text { law should (i) establish full operational independence } \\
\text { of the SBIF, including new provisions for the } \\
\text { appointment for a minimum-non coincident with the } \\
\text { President's - term for the Superintendent; (ii) ensure } \\
\text { adequate legal protection for supervisors when } \\
\text { discharging their duties in good faith; (iii) establish a } \\
\text { separate budget for the SBIF; and (iv) strengthen the } \\
\text { employment conditions of the staff of the SBIF to } \\
\text { protect them against undue dismissal. } \\
\text { These reforms should be matched by enhanced } \\
\text { accountability on the part of the SBIF. In this respect, } \\
\text { it could be useful to introduce a quality control } \\
\text { mechanism for the continuous monitoring of } \\
\text { supervisors' work. }\end{array}$ \\
\hline Licensing and Structure (BCPs 2-5) & $\begin{array}{l}\text { Empower the SBIF, in both the licensing and the } \\
\text { ongoing supervisory processes, to reject and withdraw } \\
\text { licenses and to prevent the appointment of directors } \\
\text { and senior managers, as well as controlling } \\
\text { shareholders, that do not have the proper skills } \\
\text { expertise. }\end{array}$ \\
\hline $\begin{array}{l}\text { Prudential Regulations and Requirements } \\
\text { (BCPs 6- 15) }\end{array}$ & $\begin{array}{l}\text { Speed up the introduction of market risks regulations } \\
\text { to include capital charges for these risks. } \\
\text { Expedite the provision of means to the FIU to rapidly } \\
\text { achieve observance of the AML/CFT laws and } \\
\text { regulations. Define the role of financial sector } \\
\text { supervisors in AML/CFT matters. }\end{array}$ \\
\hline Methods of Ongoing Supervision (BCPs 16-20) & $\begin{array}{l}\text { Enlarge the scope of consolidated supervision, } \\
\text { including clear coordination mechanisms and clear } \\
\text { rules for the determination of the lead supervisor or } \\
\text { coordinator for financial conglomerates. } \\
\text { Require a single external auditor for the whole group. }\end{array}$ \\
\hline Information Requirements (BCP 21) & Expedite the adoption of IASs. \\
\hline Formal Powers of Supervisors (BCP 22) & Expand bank resolution options available for the SBIF. \\
\hline
\end{tabular}

\section{Authorities' response}

70. The Chilean authorities indicated that they assign a high priority to complying with best practices regarding money laundering. In their opinion, the assessment of Principle 15 regarding Money Laundering did not reflect the improvements that have taken place during the last few months. In December 2003 a law was enacted that created a specialized agency to prevent Money Laundering, the Financial Analysis Unit (UAF). The UAF is performing its 
duties normally. Since May 2004, it is mandatory for banks, their subsidiaries, and the savings and loans cooperatives to report on suspicious transactions and to comply with strict "know-your-customer rules" procedures.

\section{IMPLEMENTATION OF THE IOSCO ObJeCtives AND PRINCIPLES OF SECURITIES REGULATION}

\section{A. General}

71. The assessment of the Chile's observance of IOSCO Principles ${ }^{32}$ benefited from interviews with officials of the SVS, visits to two of the three Chilean stock exchanges and meetings with a number of officials in the Chilean brokerage community, corporate issuers, and money management firms, as well as knowledgeable academics in the area. Additionally, after the missions, several members of the international accounting and legal community with knowledge of Chile were interviewed by telephone. Additional information was collected by a review of applicable Chilean laws, SVS regulations and publicly available information on the Chilean securities markets and the insights provided by other members of the Chile FSAP team.

\section{B. Institutional and Macroprudential Setting, Market Structure—Overview}

72. The primary regulatory agency over the Chilean capital markets is the SVS. The latter has jurisdiction over the Chilean stock exchanges, companies registering securities for public sale, brokerage firms, collective investment funds (including open-end mutual funds, closedend funds, housing funds, foreign investment funds, and university education funds), accounting industry and private credit rating agencies.

73. Banks are separately regulated by the SBIF. Banks are prohibited from engaging in equity trading for their own account or for clients unless they create a separate registered brokerage subsidiary, subject to SVS oversight. Banks may engage in all other securities activities, including government and corporate debt, where they are significant market participants. To the extent that bank activities in the debt markets are covered by the Chilean securities laws, the SBIF is authorized to enforce the applicable provisions. As such two separate regulatory schemes exist in this market.

74. The dominant institutional investors in Chile are the seven privately operated pension funds. All employees are required to make annual contributions to the pension fund of their choice. These institutions control assets exceeding US\$49 billion, far exceeding the approximately US\$8.4 billion controlled by mutual funds in Chile. The SAFP is a separate

\footnotetext{
${ }^{32}$ While the main assessor was Mr. Jonathan Katz (U.S. SEC), principle 30 concerning securities clearance and settlement systems is based upon the report prepared by another member of the FSAP team, Mr. Marc Bayle (ECB).
} 
regulatory agency, which oversees the activities of these pension funds. It has a staff of 141 , more than the number of SVS staff assigned to securities regulation. It also has greater direct authority over pension funds than the SVS has over brokers or mutual funds.

\section{General Preconditions for Effective Securities Regulation}

75. The effectiveness of any system of securities regulation is heavily dependent upon the existence of a strong, independent and efficient judicial system. A securities regulator's enforcement program is only a credible deterrent if the judiciary will act decisively and swiftly. In Chile, judicial delay is a serious problem. Judicial proceedings and appellate review may continue for as long as ten years. Delays of this length vitiate the deterrent effect of the action taken. An effective judiciary must also be fully trained in adjudicating complex financial cases and judicial interpretations and applications of the law must be consistent and fair. The capacity of the judiciary to adjudicate complex cases should be carefully examined.

\section{Main Findings}

76. The Chilean regulatory system lacks sufficient powers and or institutions necessary to respond to major systemic failures if one or more brokerage firms or mutual funds fail. The SVS should have the power to intervene in any failure by a regulated firm, to appoint a receiver or administrator. The administrator should be able to immediately assume control of a firm to safeguard customer assets for orderly distribution or transfer and to complete open unsettled transactions so that one firm's failure does not result in the failure of other firms on the opposite side of open positions. Ideally, a central insurance or guaranty fund should be created, under the administration of either a stock exchange or the Central Securities Depository (DCV) to provide sufficient liquidity to cover unfilled open positions and ensure an orderly termination of activities. This approach would be a more effective and less expensive system than the current system based upon minimum firm capital positions (which may be too low) and each firm obtaining private insurance (Principles 24, 29, 30).

77. The SVS requires additional legal powers and more resources. In addition to intervention powers, the SVS should be provided regulatory jurisdiction over investment advisers, when an adviser is not regulated as a brokerage firm or as a manager of mutual funds. The SVS should also have the authority to engage in negotiated settlements to address securities law violations, a legal question that is currently in dispute and employ a larger number of enforcement staff. The SVS also must have the authority and the capacity to obtain financial records and other relevant evidence from banks and other entities not directly subject to its regulation (Principles 3, 8, 9).

78. In Chile securities transactions, unless exempted, must be completed on a stock exchange. Exemptions include government, central bank and other public debt, and nonequity securities issued by a bank or finance company. As a result there is a large OTC government debt market that is only partially regulated and partially transparent. While Chilean securities firms must report their OTC debt trading to a stock exchange on a one day cycle, the requirement does not apply to bank trading. This gap is significant as Chilean 
banks are the dominant force in the OTC market. As a result the daily composite information published by the Chilean stock exchanges is only a partial summary. Also, the largest Chilean banks have developed a private electronic trading system that is not available to Chilean brokerage firms or institutional investors. This raises a host of issues in the areas of best execution, market transparency and public availability of market prices for asset valuation by intermediaries. The lack of an effective standard clearance and settlement system for the OTC market may raise systemic risk issues (Principles 3, 24, 25, 26, 27, 30).

79. A related problem is the lack of any uniform business practices or regulatory policy in the Chilean repo market (known as "pactos"). Repo markets in most countries are largely unregulated, reflecting the fact that participants tend to be large sophisticated institutions engaged in negotiated transactions involving high quality, fully collateralized trades of very limited duration. However in most markets there are a variety of safeguards to promote a safe and efficient market. In Chile there is no standard master agreement governing the terms of a repo and clarifying the rights of the participants in the event of market or credit risks. There are also no consistent policies on transfer of collateral and on audit trails for these instruments, making regulatory oversight of the entire OTC market difficult and creating legal uncertainty in the event of a failure. While the pactos market is acknowledged to be quite large, there are no accurate figures on the actual size, either in terms of the nominal value of the underlying assets, the cash value of the transactions or the number of transactions daily (Principles 29, 30).

80. The Chilean regulatory system for securities industry professionals, including brokerage firms, mutual funds, investment advisers and banking personnel processing transactions for their brokerage affiliates, does not have any meaningful qualification or education standards and no testing program. Anyone with a high school degree who has not been convicted of a crime or been bankrupt may work in the securities industry. This is coupled with the lack of comprehensive regulatory requirements for firms to have internal control or risk management programs or internal compliance offices to monitor firm personnel. This results in the SVS having exclusive responsibility to monitor and enforce compliance with Chilean securities laws without the benefit of access to internal compliance records. This lack of professional standards may affect investor confidence in the Chilean markets, both by Chilean and international investors (Principle 23).

81. The Chilean private securities markets (especially equity and corporate debt markets) are widely recognized as illiquid. Illiquid markets tend to be more susceptible to illegal market activity. In Chile a variety of related factors may increase the risk of illegal activity in the markets. These factors include the lack of market intermediaries such as market-makers or specialists, few active professional traders, an inability to borrow securities so as to sell short easily, the lack of derivative instruments needed to hedge market risk, no customer margin regulations and long-standing capital adequacy formulas that may be outdated and insufficient to establish that brokerage firms have sufficient capital to operate (Principles 8, $26,28)$. 
82. The Chilean standard for determining an auditor's independence permits an auditor to own up to 3 percent interest in an audit client. This is not consistent with best international practice and should be revised. Even a 3 percent interest in a client could be significant and influence the objectivity and quality of the audit work performed. Auditor independence is a cornerstone of any system of securities regulation and should never be subject to question (Principle 16).

83. Chilean accounting and auditing standards are the responsibility of the College of Accountants of Chile (CCC), a private professional organization. The CCC operates the Chilean Accounting Standards Board (CASB) primarily by reliance on a staff of part-time personnel, who are employed by the industry it oversees. This structure should be carefully examined as it affects and may limit the appearance of accounting integrity that a standard setting board must achieve. Given the size of the Chilean profession, its close ties to international firms and the increasing convergence of accounting standards worldwide, consideration should be given to adopt worldwide standards, such as IAS/IFRS or U.S. GAAP (Principle 16).

84. The Chilean system for regulating companies issuing and selling securities to the public is a hybrid of a disclosure-based system with a merit-based system. After a company completes the registration of its securities with the SVS, if it wants to offer its securities to the AFPs, it must submit an application to the Risk Rating Commission (CCR), a quasigovernmental Board (the Board is composed of senior government officials and private sector representatives) that determines whether issuers' securities are suitable for investment by the AFPs. The CCR decision is based upon a confidential review of a company's prospectus and rating agency reports submitted by the issuer. For equity offerings issuers must submit two rating reports. Only one rating report is required for debt offerings. While CCR's decision generally reflects the conclusion of the rating agencies it may deviate and occasionally does so. Its decisions are short letters to the company that do not contain an explanation for the Committee's decision, and publication of a notice of the decision in the Official Gazette. Because the AFPs control most of the available investment capital in Chile, a denial by the CCR may prevent a company from completing a public offering. Chile should consider whether it is appropriate for a single informal board substantially to control access to the Chilean capital markets. An alternative approach, in which each AFP would be required to have an internal process for determining the suitability of an investment could achieve the same benefits and, at the same time, provide greater diversification in investment decisions and increased liquidity across the Chilean capital markets.

85. The Chilean regulatory structure is premised upon separately registered and regulated independent banks, brokers and investment intermediaries. Increasing consolidation into financial holding companies is resulting in something closer to a unified financial services industry. Separation of regulatory oversight results in no single regulator being able to examine the financial soundness and capital adequacy of the entire holding company structure. 


\section{E. Recommended Action Plan and Authorities' Response to the Assessment}

\section{Recommended Actions to Improve Compliance with the IOSCO Objectives and Principles of Securities Regulation}

\begin{tabular}{|c|c|}
\hline Subject & Recommended Action and Time-Frame \\
\hline Principles relating to the regulator, (CPs $1-5)$ & $\begin{array}{l}\text { Statutory authority is required to regulate investment advisers } \\
\text { and for the SVS to respond to failures by brokerage firms or } \\
\text { mutual funds. } \\
\text { Increased staffing and financial resources for the SVS }\end{array}$ \\
\hline Principles of self-regulation (CPs 6-7) & $\begin{array}{l}\text { Stock exchanges should expand their regulatory inspection and } \\
\text { oversight programs. }\end{array}$ \\
\hline $\begin{array}{l}\text { Principles for the enforcement of securities } \\
\text { regulation (CPs } 8-10)\end{array}$ & $\begin{array}{l}\text { Judicial efficiency and speed must be addressed } \\
\text { The SVS should clarify its ability to enter into negotiated } \\
\text { settlements of enforcement actions. }\end{array}$ \\
\hline $\begin{array}{l}\text { Principles for cooperation in regulation (CPs 11- } \\
\text { 13) }\end{array}$ & $\begin{array}{l}\text { Existing bank secrecy limits must be eliminated. } \\
\text { Formal cooperation agreements between regulators should be } \\
\text { completed. }\end{array}$ \\
\hline Principles for issuers (CPs 14-16) & $\begin{array}{l}\text { The current informal accounting standards process should be } \\
\text { reexamined. } \\
\text { The current auditor independence standard should be amended. }\end{array}$ \\
\hline $\begin{array}{l}\text { Principles for collective investment schemes } \\
\text { (CPs 17-20) }\end{array}$ & $\begin{array}{l}\text { Mutual fund record keeping, internal controls asset custody and } \\
\text { sales practice standards should be established. }\end{array}$ \\
\hline $\begin{array}{l}\text { Principles for market intermediaries (CPs 21- } \\
\text { 24) }\end{array}$ & $\begin{array}{l}\text { Following passage of legal authority, regulation of investment } \\
\text { advisers should be initiated. } \\
\text { Professional competency standards for securities industry } \\
\text { professionals should be developed. } \\
\text { Standards for investment suitability, internal controls and } \\
\text { compliance should be developed. } \\
\text { Improved oversight and transparency in the OTC debt market is } \\
\text { required. }\end{array}$ \\
\hline Principles for the secondary market (CPs 25-30) & $\begin{array}{l}\text { Current standards for capital adequacy and risk management } \\
\text { should be reexamined. } \\
\text { Clearance and settlement and payment systems must be } \\
\text { improved to provide adequate protection for investors and to } \\
\text { ensure against systemic failures within the securities markets. } \\
\text { The SVS or another entity must have the legal authority to } \\
\text { respond promptly to failures by regulated entities, such as } \\
\text { brokerage firms or mutual funds. }\end{array}$ \\
\hline
\end{tabular}

\section{Authorities' response}

86. The Chilean authorities agreed on the need to strengthen the compliance programs and suitability standards for mutual funds and intermediaries, and indicated that some reforms have already been included in CMII. However, they disagreed with the assessment that there were no rules in this area. They stressed that principles regarding duties for intermediaries and fund managers were well defined in the law and its operational norms. The SVS has units specializing in the surveillance, investigation and enforcement of 
operations performed by such intermediaries and has taken corrective actions on many occasions.

87. The authorities also disagreed with the view that the different tax treatment of liquid and illiquid shares as regards the capital gains tax was problematic. In their view, it provided instead an incentive for illiquid firms to float a larger amount of their capital and obtain liquidity and, hence, tax advantages.

\section{The IMf Code of Good Practices on Transparency in Monetary Policy}

\section{A. General}

88. This assessment examines the observance by the Central Bank of Chile (BCCh) of the IMF's Code of Good Practices on Transparency in Monetary and Financial Policies (MFP Transparency Code) for monetary policy. The assessment was based on pre-mission work; a review of relevant laws, regulations, and policies; documentation provided on the $\mathrm{BCCh}$ website and in a variety of official BCCh publications; and on discussions with the $\mathrm{BCCh}$ and market participants. The assessment was based on the MFP Transparency Code, and has taken into account the implementation issues mentioned in the Supporting Document to the MFP Transparency Code. The Chilean authorities cooperated fully with the assessment and provided all of the necessary information and documentation requested by the mission.

\section{B. Main Findings}

\section{Clarity of roles, responsibilities, and objectives of the central bank for monetary policy}

89. The assessment reveals a high degree of compliance with the Transparency Code, including in the objectives and responsibilities of the central bank. The target and instrument autonomy of the Central Bank of Chile is very strong by virtue of being enshrined in the Constitution. Nevertheless, to ensure that there are no conflicts between price and exchange rate stability in the current inflation targeting regime, further clarification could be useful in two areas. First, there is an element of uncertainty in the interpretation of the statutory definition of the monetary policy objective, since currency stability may refer to internal (price) or external (exchange rate) stability. While this could be viewed as a strength on account of the greater flexibility it provides to the Central Bank in adjusting its policies, it may also be viewed as a weakness to the extent that it does not explicitly support the current inflation targeting regime. Second, the institutional responsibilities of the central bank in determining the exchange rate regime could be more explicitly spelled out.

\section{Open process for formulating and reporting monetary policy decisions}

90. The process for monetary policy formulation, implementation and communication is highly transparent. The framework for monetary policy, its targets, instruments and procedures are discussed in non-technical notes, as well as in more detailed studies, and numerous publications available on the web-site. Resolutions are published in the Official 
Gazette and any changes in the setting of monetary policy instruments are explained in the Monetary Policy Report and immediately communicated to market participants. Practices of transparency and public disclosure are also upheld through the publication of Board meetings minutes (including individual votes of members present, their arguments and opinions expressed) within a month and a half of the meetings. The regulatory framework and operating guidelines for the central bank's counterparts in the financial sector are publicly available on the web-site.

\section{Public availability of information on monetary policy}

91. An extensive set of publications is available on the web-site, including the Monetary Policy Report, Economic Policy Papers, the Economic and Financial report, the Monthly Bulletin and the Annual Report. The public availability of two additional documents is particularly helpful in enhancing understanding of monetary policy issues, namely "Monetary Policy of the Central Bank of Chile: Objectives and Transmission" and "The Central Bank of Chile and the Economy." The latter introduces the central bank's purpose, functions, and main regulations as well as the principal macroeconomic time series since 1986 . The proceedings of annual conferences, representing an important platform where economic issues are debated, are also available on the web-site, together with the text of public addresses of central bank officials.

\section{Accountability and assurances of integrity by the central bank}

92. Accountability for the conduct of monetary policy is ensured by virtue of the fact that the Bank is to inform the President of the Republic and the Senate in the performance of its duties, its policies and any regulations having general applicability. Although de jure the $\mathrm{BCCh}$ is only required to provide information on its policies, in practice it also provides extensive explanations, thereby justifying the appropriateness of its policy decisions. The central bank is required to consider the general orientation of the Government's economic policies when passing a resolution through the Board and may obtain any necessary information from other public institutions in the conduct of monetary policy. The institutional relationship is thus one of coordination, subject to the primacy of the central bank objectives. The sharing of information between the monetary and the fiscal authority is facilitated by the presence of the Finance Minister in Board meetings. The Minister of Finance attends Board meetings (including monetary policy meetings) with veto rights subject to detailed procedures and limitations as set out in the law. A number of internal governance provisions will shortly be published on the $\mathrm{BCCH}$ web-site, significantly enhancing operational transparency and market perceptions of integrity. 


\section{Recommended Action Plan and Authorities' Response to the Assessment}

Recommended Plan of Actions to Improve Observance of IMF's MFP Transparency Code Practices-Monetary Policy

\begin{tabular}{|l|l|}
\hline Reference Practice & Recommended Action \\
\hline Practices 1.2.4 and 4.2.2 & $\begin{array}{l}\text { Pursue publication of internal norms regarding acquisitions and } \\
\text { procurement on the BCCH web-site together with a brief note on internal } \\
\text { governance. }\end{array}$ \\
\hline Practice 4.4 & $\begin{array}{l}\text { Pursue the web-site publication of a note on internal rules regarding the } \\
\text { personal financial affairs of the staff. }\end{array}$ \\
\hline
\end{tabular}

\section{Authorities' response}

93. In the Chilean authorities' view, there is no need for clarifying the institutional responsibility for foreign exchange rate policy, as the law clearly establishes this responsibility. They indicated that the BCCh is a public law (derecho público) institution, which is autonomous and of a technical nature. As established by its Constitutional Organic Act (COA), the BCCh must "provide for the stability of the currency and the normal functioning of external and internal payments." In that regard, the BCCh receives ample public authorization to regulate the amount of currency and credit in circulation, to perform credit and foreign exchange transactions, and to exclusively issue regulatory provisions regarding monetary, credit, financing and foreign exchange matters. The exclusiveness to issue foreign exchange regulations derives from the fact that before the COA's enactment, such authority pertained to the Monetary Council, and was later transferred to the BCCh, in accordance with the constitutional autonomy granted to it by the 1980 Constitutional Act of Chile (CA). Furthermore, the BCCh has always been empowered to perform and regulate foreign exchange transactions aimed at accomplishing its institutional role.

94. Based on the foregoing, and on several judicial pronouncements ${ }^{33}$ (i) the BCCh is independent from the State of Chile in the fulfillment of the public duty conferred to it by the law; (ii) it is subordinated not to a public authority, but to the $1980 \mathrm{CA}$ and the COA that provide for its composition, organization, duties, and authorities; and (iii) it is the exclusive entity empowered to issue, among others, regulatory provisions regarding foreign exchange matters.

95. Pursuant to the prevailing Chilean legal institutional framework, the President of the Republic lacks the authority to regulate those matters, which the law confers exclusively to the BCCh. Such provision, enshrined in sections 6 and 7 of the $1980 \mathrm{CA}$, penalizes its infringement with the nullity of the corresponding act without prejudice of administrative

\footnotetext{
${ }^{33}$ The latest being a decision granted by the Court of Appeals of Santiago dated September 26, 2003, and
} confirmed by the Supreme Constitutional Court. 
liabilities. The foregoing explains that, regarding the relationship between the BCCh and the Executive power, the COA sets forth specific provisions on the BCCh's public duty. These include: i) to perform in accordance with the general orientation of the government's economic policy; ii) to inform the President of the Republic and the Senate as provided for in the law; iii) to include the Minister of Finance at Board meetings with the right to be heard and the power to suspend the enforceability of any decision or resolution passed by the Board within a period not to exceed 15 days, plus the right to veto the enforceability of foreign exchange restrictions, in which event the respective restriction may be adopted only with the favorable vote of all the Board members.

96. In addition, the Chilean legal framework grants the BCCh the authority to directly engage in and regulate foreign exchange transactions. The BCCh may, for example, purchase and sell foreign currency; issue notes payable in US dollars or denominated in foreign currency; enter into derivative transactions and hedge agreements. Likewise, it may regulate foreign exchange transactions by setting limitations and restrictions seeking to fulfill its above-described legal purpose.

97. Therefore, the Chilean authorities do not share the view implicit in the comments in Principle 1.1.4 that "...the BCCh statute does not explicitly refer to the institutional responsibility for the choice of the exchange of the exchange rate regime." As the assessment reports, the BCCh modified the foreign exchange policy in use of its exclusive and clear legal authority. In that regard, there are several examples confirming said legal exercise, both prior to the COA and after its enactment, that demonstrate the exclusive exercise of its authority to establish and amend the foreign exchange regime's components in effect in Chile. Those resolutions were adopted within the prevailing legal framework, with the participation of the Executive Power acting through the Ministry of Finance as provided for in the COA, duly informed to the public when published in the Official Gazette, and reported to the Senate in the form and channels set forth in the referred COA.

98. With respect to principles 1.2.4, 4.2.2 and 4.4, steps are being taken to increase the transparency in each of the issues. In the short term, this will be reflected in the publication of procurement procedures and a set of norms governing the ethical and personal conduct of the staff. A more detailed description of the functioning of the internal audit unit will be made public as soon as it becomes available. 


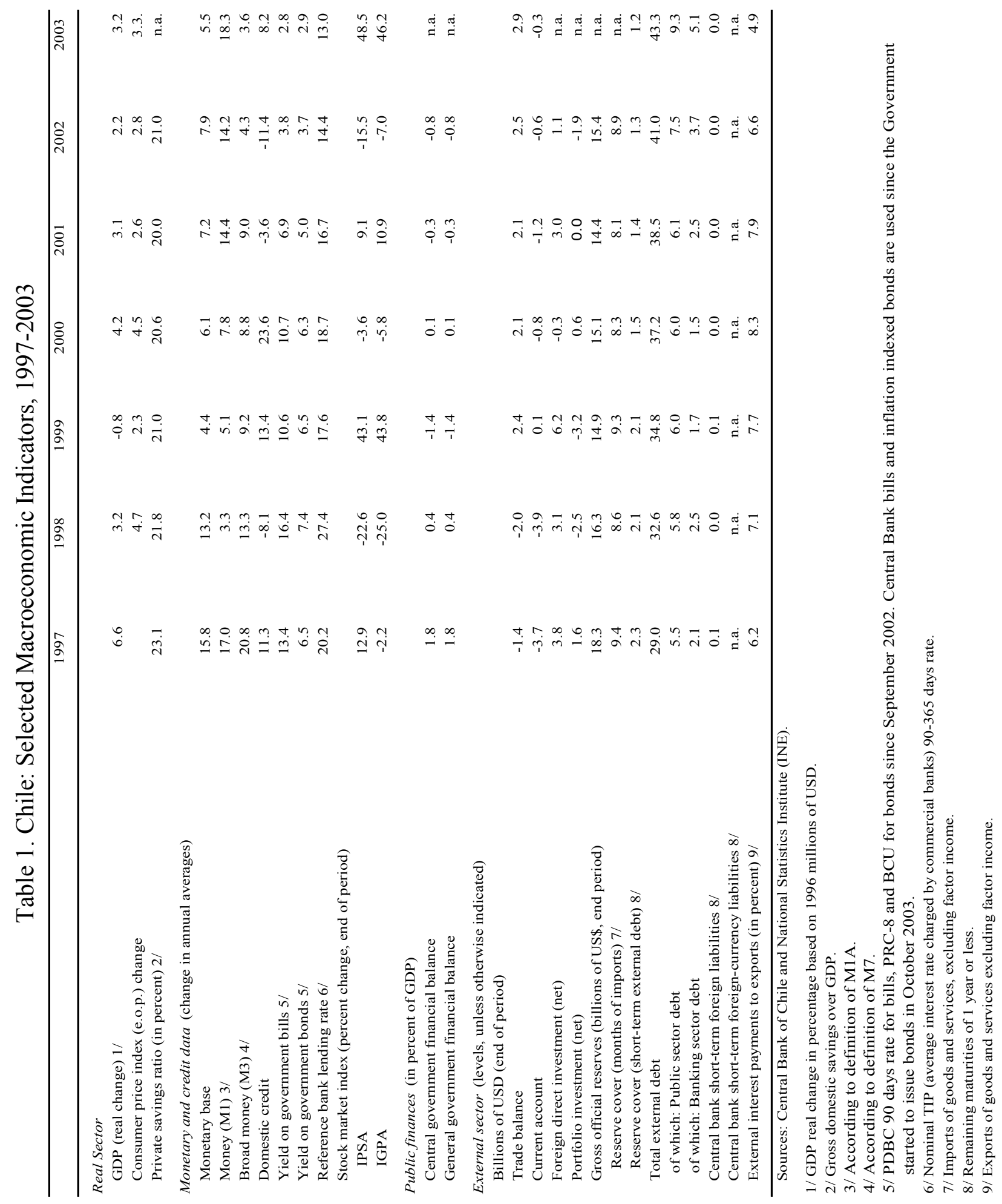




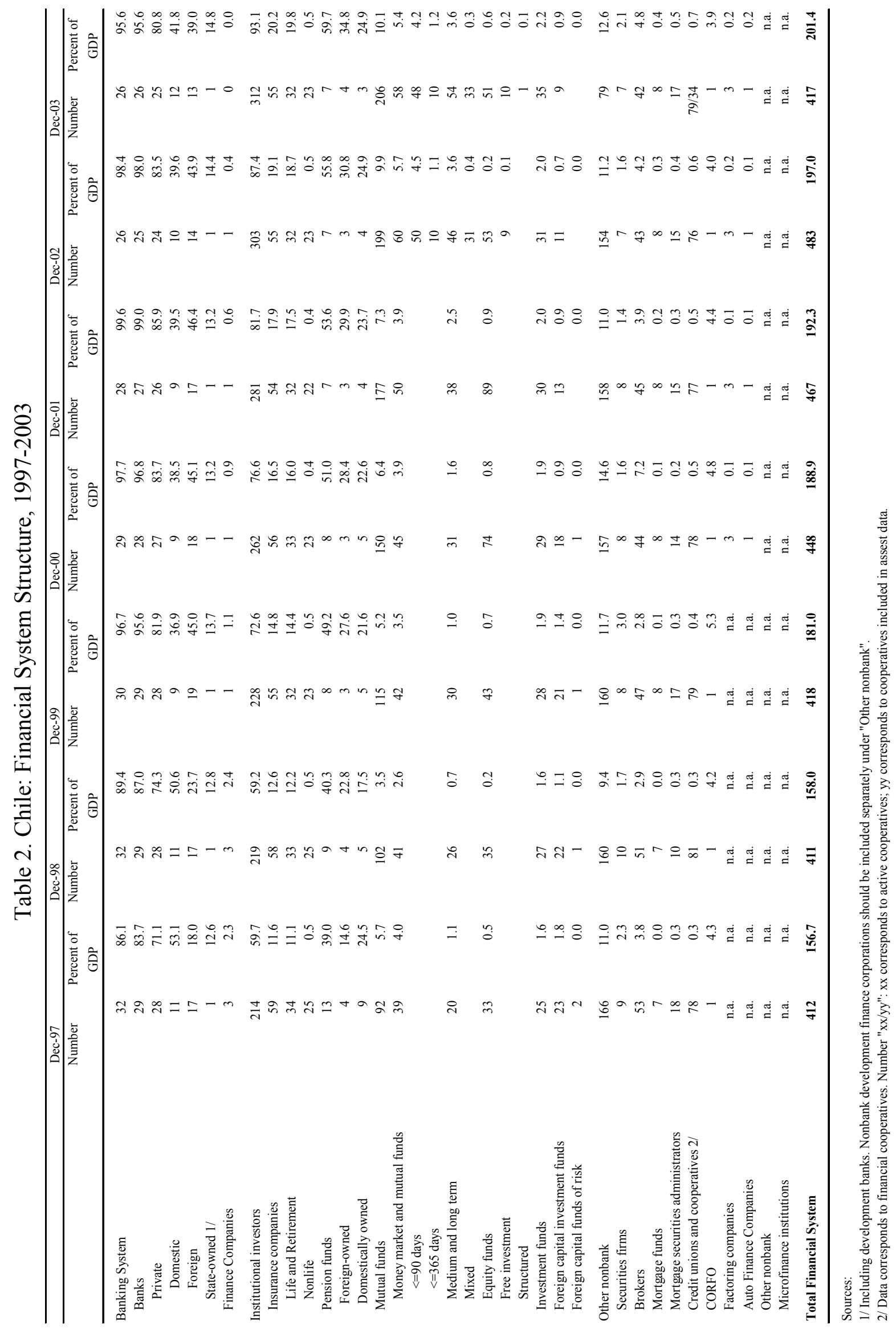


Table 3. Chile: Financial Soundness Indicators, 1997-2003

(In percent, unless otherwise indicated)

\begin{tabular}{|c|c|c|c|c|c|c|c|}
\hline & Dec-97 & Dec-98 & Dec-99 & Dec-00 & Dec-01 & Dec-02 & Sep-03 \\
\hline \multicolumn{8}{|l|}{ Banking Sector Indicators } \\
\hline \multicolumn{8}{|l|}{ Capital Adequacy $1 /$} \\
\hline Regulatory capital to risk-weighted assets $2 /$ & n.a. & 12.5 & 13.5 & 13.3 & 12.7 & 14.0 & 14.5 \\
\hline Regulatory Tier I capital to risk-weighted assets3/ & n.a. & 11.0 & 10.6 & 10.5 & 9.9 & 11.1 & 11.5 \\
\hline Capital (net worth) to assets & 7.4 & 7.5 & 7.8 & 7.5 & 7.2 & 7.2 & 7.5 \\
\hline \multicolumn{8}{|l|}{ Asset composition and quality } \\
\hline Consumer loans & 10.4 & 9.2 & 8.4 & 7.9 & 7.7 & 8.5 & 9.1 \\
\hline Mortgage loans & 14.2 & 15.2 & 16.6 & 16.7 & 16.6 & 17.3 & 18.3 \\
\hline Commercial loans & 57.0 & 57.4 & 55.8 & 55.2 & 56.6 & 54.2 & 52.8 \\
\hline FX liabilities to total liabilities & 9.5 & 10.6 & 10.9 & 10.4 & 12.2 & 15.5 & 16.6 \\
\hline Net open positions in equities to capital & n.a. & n.a. & n.a. & n.a. & n.a. & n.a. & n.a. \\
\hline NPLs to gross loans 4 / & 1.2 & 1.6 & 1.8 & 1.9 & 1.8 & 2.0 & 2.0 \\
\hline Consumer & 0.8 & 1.2 & 0.9 & 0.9 & 0.9 & 0.8 & 0.8 \\
\hline Mortgage & 0.4 & 0.5 & 0.6 & 0.8 & 0.9 & 1.1 & 1.2 \\
\hline Commercial & 1.6 & 1.9 & 2.2 & 2.4 & 2.1 & 2.4 & 2.4 \\
\hline NPLs net of provisions to capital & 5.2 & 8.7 & 9.2 & 10.1 & 10.1 & 10.5 & 10.2 \\
\hline Consumer & n.a. & n.a. & n.a. & n.a. & n.a. & n.a. & n.a. \\
\hline Mortgage & n.a. & n.a. & n.a. & n.a. & n.a. & n.a. & n.a. \\
\hline Commercial & n.a. & n.a. & n.a. & n.a. & n.a. & n.a. & n.a. \\
\hline Large exposures to capital 5/ & n.a. & n.a. & n.a. & 1.8 & 1.8 & 1.3 & 1.3 \\
\hline Gross asset position in derivatives to capital & n.a. & n.a. & n.a. & n.a. & n.a. & n.a. & n.a. \\
\hline Gross liability position in derivatives to capital & n.a. & n.a. & n.a. & n.a. & n.a. & n.a. & n.a. \\
\hline Spread between highest and lowest interbank rates $6 /$ & 4.8 & 4.5 & 2.1 & 2.4 & 0.5 & 0.1 & 0.0 \\
\hline \multicolumn{8}{|l|}{ Earnings and Profitability } \\
\hline ROA 7/ & 1.0 & 0.9 & 0.7 & 1.0 & 1.3 & 1.1 & 1.3 \\
\hline ROE 7/ & 13.7 & 11.5 & 9.4 & 12.7 & 17.7 & 14.4 & 16.4 \\
\hline Interest margin to gross income & 80.7 & 75.4 & 75.0 & 75.4 & 75.8 & 80.1 & 61.4 \\
\hline Noninterest expenses to gross income & 63.5 & 59.3 & 57.7 & 57.0 & 56.2 & 55.2 & 53.7 \\
\hline Personnel expenses to noninterest expenses & 56.2 & 55.3 & 55.7 & 55.7 & 56.0 & 53.9 & 54.3 \\
\hline Trading and fee income to total income & 6.6 & 6.7 & 6.4 & 5.0 & 4.4 & 5.5 & 6.0 \\
\hline Spread between reference loan and deposit rates $8 /$ & 3.3 & 4.5 & 3.7 & 5.1 & 5.3 & 3.8 & 3.3 \\
\hline \multicolumn{8}{|l|}{ Liquidity } \\
\hline Liquid assets to total assets & 16.6 & 15.2 & 17.7 & 16.9 & 17.2 & 18.7 & 16.9 \\
\hline Liquid assets to total short-term liabilities & 18.3 & 17.8 & 20.5 & 20.0 & 20.6 & 22.0 & 20.2 \\
\hline Customer deposits to total (non-interbank) loans & 72.7 & 75.2 & 81.3 & 80.6 & 78.9 & 80.8 & 77.6 \\
\hline FX liabilities to total liabilities & 9.5 & 10.6 & 10.9 & 10.4 & 12.2 & 15.5 & 16.6 \\
\hline Average bid-ask spread in the securities market 9/ & & & & 10.0 & 8.0 & 6.0 & 5.0 \\
\hline \multicolumn{8}{|l|}{ Household Sector Indicators } \\
\hline Rate of growth of financial assets & n.a. & n.a. & 11.5 & 9.9 & 4.9 & 4.4 & n.a. \\
\hline Rate of growth of liabilities $10 /$ & 30.7 & 19.5 & 7.6 & 4.1 & 7.5 & 3.4 & 10.5 \\
\hline Net financial assets to disposable income & n.a. & 82.8 & 96.2 & 101.6 & 104.1 & 102.9 & n.a. \\
\hline Debt servicing cost to disposable income 11/ & 11.7 & 12.6 & 12.3 & 12.6 & 12.0 & 12.6 & n.a. \\
\hline \multicolumn{8}{|l|}{ Corporate sector indicators } \\
\hline Corporate debt to equity ratio $10 /$ & 55.9 & 61.1 & 77.8 & 70.0 & 75.3 & 79.5 & 81.3 \\
\hline Growth rate of company liquidations & -8.2 & 86.6 & 12.8 & 7.8 & 17.1 & 2.8 & n.a. \\
\hline EBITDA to interest expenses & 2.4 & 1.7 & 1.1 & 1.1 & 1.3 & 1.5 & n.a. \\
\hline ROA & 9.8 & 7.3 & 4.1 & 5.8 & 6.1 & 4.4 & n.a. \\
\hline ROE & 6.3 & 4.6 & 2.3 & 3.4 & 3.5 & 2.4 & n.a. \\
\hline \multicolumn{8}{|l|}{ Insurance sector indicators -Life Insurance } \\
\hline Growth rate of gross premiums written ( $\%$ change from last $\mathrm{Yr}$ ) & 11.3 & -2.1 & 17.8 & 15.6 & 9.3 & -8.2 & n.a. \\
\hline Life Surplus to Total Assets & -0.5 & -1.5 & 1.7 & -0.6 & 0.5 & 0.2 & n.a. \\
\hline Investment income / Investment assets & 96.2 & 96.7 & 96.8 & 96.6 & 95.6 & 96.5 & n.a. \\
\hline \multicolumn{8}{|l|}{ Insurance sector indicators - Non Life Insurance } \\
\hline Growth rate of gross premiums written ( $\%$ change from last $\mathrm{Yr}$ ) & -3.8 & -3.2 & -3.5 & 6.8 & 21.8 & 24.8 & n.a. \\
\hline Combined ratio & 99.8 & 98.1 & 101.0 & 105.9 & 97.9 & 90.4 & n.a. \\
\hline Investment income to investment assets & 47.1 & 48.8 & 47.1 & 41.7 & 37.1 & 36.6 & n.a. \\
\hline Underwriting profit to net investment income & 5.5 & 6.4 & 7.8 & 5.1 & 5.9 & 4.3 & n.a. \\
\hline Solvency Margin & & & & & & & \\
\hline
\end{tabular}

Source:

1/ The indicators are calculated in consolidated terms for branches and subsidiaries abroad starting on June 2002

$2 /$ Regulatory capital is equivalent to equity.

3/ Tier 1 regulatory capital is the basic capital.

4/ Overdue loans are unpaid loans with more than 90 days since the due date. In the case of credit in quotas, the general rule is to account

for the quota amount only. The only exception is when the loan has an accelaration clause in the agreement. As of October 2003.

$5 /$ Corresponds to a commercial portfolio greater than 20,000 UF and $2 \%$ of the equity of the financial institution.

6/ One day non readjustable interbank rate.

7/ ROA and ROE are calculated using annualized terms of final utility. To annualize, they are divided by the numbers of months and

multiplied by twelve. The denominator of both corresponds to the oustanding balance of the month in question.

8/ Nominal 30-89 day rate.

9/ Corresponds to PRC-8, data for October 2003

$10 /$ As of June 2003 data.

11/Data for January-September, 2003. 